\title{
TRP, a Protein Essential for Inositide-Mediated Ca²+ Influx Is Localized Adjacent to the Calcium Stores in Drosophila Photoreceptors
}

\author{
John A. Pollock, ${ }^{1}$ Arnon Assaf, ${ }^{2}$ Asher Peretz,, ${ }^{2}$ Charles D. Nichols, ${ }^{1}$ Mart H. Mojet, ${ }^{3}$ Roger C. Hardie, ${ }^{3}$ and \\ Baruch Minke ${ }^{2}$ \\ ${ }^{1}$ Center for Light Microscopic Imaging and Biotechnology and the Department of Biological Sciences Carnegie \\ Mellon University, Pittsburgh, Pennsylvania 15213-3890, '2Department of Physiology and the Minerva Center for \\ Studies of Visual Transduction, Hebrew University-Hadassah Medical School, Jerusalem 91120 Israel, and \\ ${ }^{3}$ Department of Zoology, Cambridge University, Cambridge CB2 3EJ, United Kingdom
}

The Drosophila transient receptor potential (trp) gene product (TRP) shows some structural similarity to vertebrate voltage-gated $\mathrm{Ca}^{2+}$ channels. It appears to function as a novel $\mathrm{Ca}^{2+}$ channel responsible for light stimulated, inositol trisphosphate (Ins $\mathrm{P}_{3}$ )-mediated $\mathrm{Ca}^{2+}$ entry in the fly retina. The subcellular localization of TRP protein was determined in this study using immunohistochemical staining with anti-TRP antibody (MAb83F6). TRP was localized to the base of the microvilii in a region adjacent to the presumed Ins $\mathrm{P}_{3}$-sensitive $\mathrm{Ca}^{2+}$ stores. This specific localization was supported by measuring the magnitude of a TRPdependent inward current that results from spontaneous activation of the light-sensitive channels during whole-cell recordings (the rundown current, $\mathrm{RDC}$ ). We found that reduction of the microvilli area through genetic dissection with the opsin null mutant, ninaEora, was correlated with a pronounced enhancement of the TRP-dependent inward current relative to wild type, suggesting that the TRP-dependent current was not produced along the length of the microvilli. We suggest that the functional localization of the TRP protein is on the plasma membrane loop found along the base of the rhabdomeric microvillus. Thus, the TRP channel may function in concert with the Ins $_{3}$-sensitive $\mathrm{Ca}^{2+}$ stores.

[Key words: anti-TRP antibody, phototransduction, lightsensitive channels, whole-cell recordings, Drosophila $\mathrm{mu}$ tants, immunohistochemical localization]

\footnotetext{
Received Aug. 8, 1994; revised Nov. 9, 1994; accepted Dec. 20, 1994.

We thank Drs. W. L. Pak for the generous supply of the mutants, Seymour Benzer in whose laboratory MAb83F6 was generated by J.A.P, J. Crew for help in the experiments of Figure 1, and S. Bar-Nachum for help in the experiments of Figure 4 and Table 3. We also thank Drs. Z. Selinger, B. Gillo, and J. McKay for critical reading of the manuscript. Technical assistance was provided M. Vishnawanathan, P. Maurides, and SURG/HHMI supported undergraduate researchers at CMU: R. Brendza, J. Burkman, E. Chartoff. This research was supported by NIH grant EY03529 and the German Israeli Foundation to B.M.; by NIH Grants EY05836, EY08334, EY09093, and NSF/STC Grant BIR-8920118, and March of Dimes, Basil O'Connor Award FY93-1010 to J.A.P.; and by the Science and Engineering Research Council, The Royal Society and Welcome Trust to R.C.H.

Correspondence should be addressed to Dr. Baruch Minke, Department of Physiology, The Hebrew University-Hadassah Medical School, Jerusalem 91120 , Israel.

Copyright $\odot 1995$ Society for Neuroscience $0270-6474 / 95 / 153747-14 \$ 05.00 / 0$
}

Ins $\Gamma_{3}$-induced $\mathrm{Ca}^{2+}$ entry is a key component of several cell signalling mechanisms including invertebrate phototransduction, but its mechanism is poorly understood (rev. Putney, 1990; Irvine, 1991; Berridge, 1993; Hardie and Minke, 1993; Penner et al:, 1993).

In Drosophila, the Transient Receptor Potential (TRP) protein (Montell and Rubin, 1989; Wong et al., 1989) appears to be a light-activated cation channel with a high $\mathrm{Ca}^{2+}$ permeability (Hardie and Minke, 1992, 1993; Phillips et al., 1992). In the trp mutant, in which TRP does not function, the photoreceptor potential declines to baseline during prolonged illumination; its sensitivity only recovering after about $1 \mathrm{~min}$ in the dark (Cosens and Manning, 1969; Minke et al., 1975; Minke, 1982). Wholecell voltage-clamp revealed that the relative $\mathrm{Ca}^{2+}$ permeability of the light-sensitive channels $\left(P_{\mathrm{Ca}}: P_{\mathrm{Na}}\right)$ in the trp mutant is at least 10 times less than normal (Hardie and Minke, 1992). Furthermore, the trp mutant phenotype, and the reduced $\mathrm{Ca}^{2+}$ permeability can be closely mimicked in wild-type photoreceptor cells by the application of the $\mathrm{Ca}^{2+}$ channel blocker, lanthanum $\left(\mathrm{La}^{3+}\right)$ to the external medium (Hochstrate, 1989; Suss-Toby et al., 1991; Hardie and Minke, 1992). A highly reduced lightdependent $\mathrm{Ca}^{2+}$ entry in $\operatorname{trp}$ was further corroborated from independent studies using $\mathrm{Ca}^{2+}$ selective microelectrodes in intact Drosophila flies, as well as $\mathrm{Ca}^{2+}$ indicator dyes in isolated ommatidia (Peretz et al., 1994a,b). The suggestion that the trp gene encodes a light-sensitive $\mathrm{Ca}^{2+}$ permeable channcl protein is supported by the predicted TRP amino acid sequence (Montell and Rubin, 1989) which shows homologies with the family of voltage-gated channels and in particular the vertebrate voltage-gated $\mathrm{Ca}^{2+}$ channel (dihydropyridine receptor), where approximately $40 \%$ identity is observed in the transmembrane regions S3-S6 (Phillips et al., 1992).

Several patch-clamp studies on a number of other invertebrate species have indicated that the light-sensitive channels are localized to the rhabdomeric region (Limulus, Bacigalupo and Lisman, 1983; Nagi and Stieve, 1990; Lima, Nasi, 1991; Pecten, Nasi and Gomez, 1992). However, the small diameter of the microvilli $(60 \mathrm{~nm})$ relative to the opening diameter of the patch pipette $(\sim 1 \mu \mathrm{m})$ did not allow precise localization of the lightsensitive channels along the microvilli. In Drosophila, the properties of light-sensitive channels have not been investigated directly, as they have proved to be inaccessible to the patch pipette. Furthermore, detailed studies of the light-induced current 

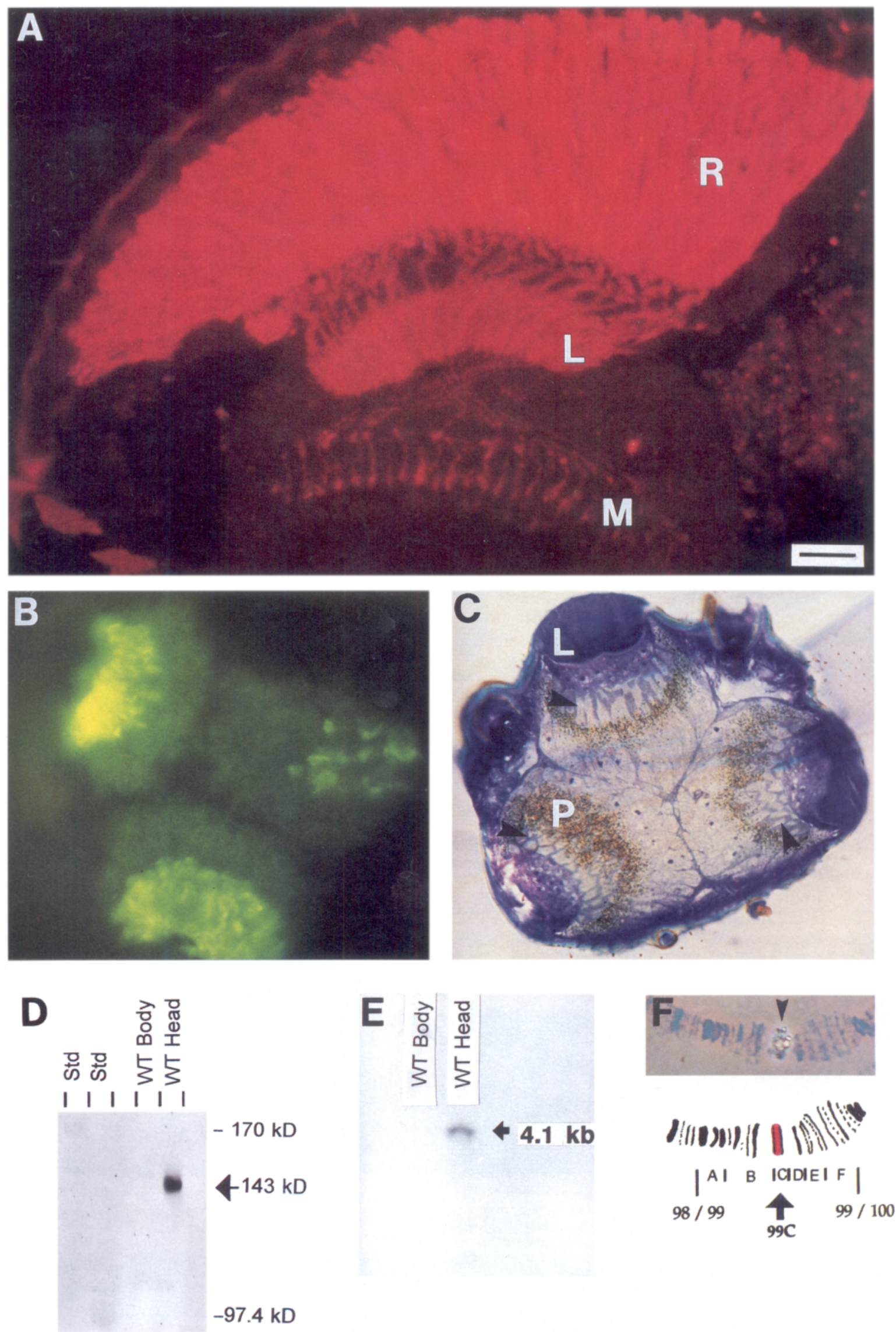

Figure 1. MAb83F6 is a mouse monoclonal antibody that specifically identifies the TRP protein. $A$, TRP protein is expressed in all eight photoreceptor cell types of the compound eye. Epifluorescent illumination reveals the intense red fluorescence of the secondary antibody with 
recorded in whole-cell recordings are limited by the kinetic and noise properties of the summed responses to single photons (quantum bumps, Yeandle, 1958). Nonetheless, we have shown that the light-dependent channels activate spontaneously during prolonged whole-cell recording, thereby becoming uncoupled from the phototransduction machinery (IIardie and Minke, 1994a,b). The resulting current, which we call the rundown current (RDC), appears to rely on activation of the trp dependent channels, that is, it is blocked by lanthanum $\left(\mathrm{La}^{3+}\right)$, or absent in a null trp mutant. Knowing the exact localization of the lightsensitive channels will contribute to our understanding of the gating mechanism of these channels.

In the present study, we have localized the TRP-protein by immunohistochemical staining with a monoclonal antibody, MAb83F6, that specifically binds to TRP. This study shows that TRP is mainly localized to the base of the microvilli and not to the entire rhabdomeric surface. The functional localization of TRP to the plasma membrane at the base of the microvilli was further supported by comparing the magnitude of the rundown current in wild-type flies, to the current in the opsin null mutant nina $E^{\text {or' }}$, in which the microvilli area is highly reduced (Harris et al., 1976; Stark and Sapp, 1978; Schinz et al., 1982; O'Tousa et al., 1989; Leonard et al., 1992). Together, these data support the model that places the functional TRP channel on the plasma membrane loops found at the base of the rhabdomere in close proximity to the $\mathrm{InsP}_{3}$-sensitive $\mathrm{Ca}^{2+}$ stores.

\section{Materials and Methods}

Fly stocks. Control animals werc whitc-cycd Drosophila melanogaster mutant for the white ( $w$ ) gene, or mutant for cinnabar and brown (cn $b w$ ), but in each case normal for trp and therefore called "wild type." Flies mutant for the transient receptor potential gene included $w ; t^{C M}$

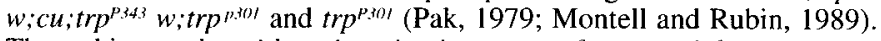
The white-eyed neither inactivation nor afterpotential mutant $w$; nina $E^{\text {ora }}$ was also used in this study. We used two alleles of ninaE ${ }^{\text {ora }}$ : (1) the ninaE $E^{\text {orul/7 }}$ allele which is an opsin Rh1 mutant lacking the opsin expressed in the photoreceptor cells R 1-R6 (O'Tousa et al., 1985, 1989: Zuker et al., 1985, Pollock and Benzer, 1988), and (2) the ninaE allele, which has a very similar phenotype to that of ninaE $E^{\text {oral }} / 7$ and contains the ort mutation in addition to the ninaE mutation (O'Tousa et al., 1989; see also Leonard et al., 1992). We found no difference between these two ninaE alleles regarding the RDC or immunohistochemical staining, consistent with the previous studics of O'Tousa et al (1989). Throughout this work ninaE ${ }^{\text {sra }}$ will designate both ninaE alleles.

Flies were grown either on standard corn meal and molasses diet or on instant Drosophila medium Formula I-24 (Carolina Biological Supply), supplemented with vitamin A (1\%). Flies were reared at $65 \%$ to
$70 \%$ relative humidity at $25^{\circ} \mathrm{C}$ (unless otherwise indicated) under regulated $12 \mathrm{hr}$ light/12 $\mathrm{hr}$ dark daily cycle.

Ommatidia preparation. Ommatidia from newly emerged adult female flies less than $4 \mathrm{hr}$ old were prepared as described previously (Hardie, 1991). Retina dissected from P13-P15 stages of female pupae were also used. Female pupae were staged according to Perry (1968; see also Waddington and Perry, 1960; Bainbridge and Bownes, 1981). Briefly, retinas were rapidly dissected in normal Ringer's solution, transferred to $\mathrm{Ca}^{2+}$-free Ringer's solution supplemented with $10 \%$ fetal calf scrum, and gently triturated with either silanized or nonsilanized glass pipettes fire polished to a diameter of approximately $200-250 \mu \mathrm{m}$. During the dissociation procedure, which requires no enzyme treatment, the surrounding pigment cells disintegrate, exposing the photoreceptor membrane. This procedure also results in the ommatidia breaking off at the fenestrated basement membrane; thus the photoreceptors lack their axon terminals. Ommatidia were used immediately after dissection.

Electrophysiology. Aliquots $(>10 \mu \mathrm{l})$ of ommatidia were allowed to settle in a small chamber, the bottom of which was formed by a clean coverslip, on the stage of an Axiovert 35 inverted microscope. Recordings were made at $\left(21 \pm 1^{\circ} \mathrm{C}\right)$, using patch pipettes pulled from borosilicate glass (fiber filled) with resistance of $10 \mathrm{M} \Omega$ for whole-cell recordings. Whole-cell recordings were achieved using standard techniques (Hardie, 1991; Ranganathan et al., 1991a). Signals were amplified using an Axopatch-1D (Axon Instruments) patch-clamp amplifier, and filtered below $2 \mathrm{kHz}$ via a four-pole Bessel filter. For measurements of the rundown current (RDC), data were usually sampled at $10 \mathrm{kHz}$ for $100 \mathrm{msec}$ when voltage steps of $50 \mathrm{msec}$ duration were applied. Series resistances were typically in the range between 8-16 M $\Omega$ Only recordings with series resistance compensation $>75 \%$ were accepted for quantitative analysis of RDC values. The histograms presented in this study were measured at a holding potential of $-60 \mathrm{mV}$, in which the measured currents were usually below $2 \mathrm{nA}$ (maximally $3 \mathrm{nA}$ ). In the experiments involving instantaneous voltage steps during run down currents, leak currents were subtracted using templates generated in the dark before rundown occurrence. In every case capacitive transients were carefully compensated before voltage steps were applied. For reversal potential measurements particular care was taken to minimize series resistance and space clamp errors defined as the estimated drop in holding potential over the length of the ommatidium, and calculated from the measured input resistance, the cell dimensions assuming a specific axoplasm resistance of $100 \Omega 2 \cdot \mathrm{cm}$ (Rall, 1969; Rall and Segev, 1985). Recordings were only accepted when the series resistance and space-clamp errors were both below $1 \mathrm{mV}$. The reversal potential data were corrected for the remaining series resistance error and a junction potential of $-2.1 \mathrm{mV}$.

Solutions. Bath Ringer's contained (in $\mathrm{mm}$ ) $120 \mathrm{NaCl}, 5 \mathrm{KCl}, 8$ $\mathrm{MgSO}_{4}, 10 \mathrm{~N}$-Tris-(hydroxymethyl)-methyl-2-amino-ethanesulfonic acid (TES). $\mathrm{CaCl}_{2}$ was added as indicated (e.g., $10 \mathrm{~mm}, 1.5 \mathrm{~mm}$, or no $\mathrm{Ca}^{2+}$ with $100 \mu \mathrm{M}$ EGTA). The pipette solution was designed to block $\mathrm{K}^{\prime}$ channel activity, and included $120 \mathrm{~mm} \mathrm{CsCl}, 15 \mathrm{~mm}$ tetraethyl ammonium (TEA) Cl, $2 \mathrm{mM} \mathrm{MgSO}_{4}, 10 \mathrm{~mm}$ TES (junction potential, $3 \mathrm{mV}$ ).

Production of MAb83F6. Monoclonal antibody (MAb) $83 \mathrm{~F} 6$ was produced following the methods of Fujita et al. (1982). One significant

$\leftarrow$

Cy3.18, highlighting MAb83F6 in a $5 \mu \mathrm{m}$ cryosection of a normal adult head. The presence of the TRP protein is evident in the retina $(R)$. This long photographic exposure also reveals axons for R1-R6 seen projecting into the lamina $(L)$, as are the axons for cells R7 and R8 which cross at the chiasm and then project into the medulla $(M)$. The terminals of the photoreceptor axons make numerous synapses with interneurons in the optic ganglia. This expression pattern may indicate that the TRP protein may be functioning on the presynaptic membrane contributing to the control of $\mathrm{Ca}^{2+}$ flux during depolarization and neurotransmitter release. Scale bar, $15 \mu \mathrm{m}$. B. TRP is expressed in the ocellus. In a $4 \mu \mathrm{m}$ cryosection of a normal head that passes through two ocelli, grazing the third, epifluorescent illumination reveals the bright fluorescein isothiocyanate (FITC) staining of MAb83F6. The TRP protein is found adjacent to the rhabdomeres in the tripartite dorsal ocellus of the adult fly. Staining with MAb83F6 was not evident in the larval photoreceptor organ (data not shown). $C$, The ocellus structure is revealed in a bright field photomicrograph, toluidine blue stain of a $1 \mu \mathrm{m}$ plastic section, that passes through all three components of this visual organ. The lens $(L)$, rhabdomeric membranes $(a r r o w h e a d s)$ and pigment layer $(P)$ are all visible. Scale bar of $15 \mu \mathrm{m}$ applies for both $B$ and $C$. $D$, Western blot of head protein extract and body protein probed with MAb83F6 reveals that TRP is a protein of $143 \mathrm{kDa}$ expressed head. No TRP protein is detected in the body extract compatible with Northern analysis which shows only a head specific mRNA and no body RNA. Additional experiments showed that the TRP protein is associatcd with a microsomal membrane fraction and that the PI is about 8.0 (data not shown). $E$, Northern analysis with cDNA-83F6 uncovers a transcript of 4.1 kb. Northern analysis was performed on polyA ${ }^{+}$mRNA purified from adult body and head ( $1-2 \mathrm{~d}$ postemergence). These studies used PCR amplified 83F6 cDNA that was nick-translated with "'P-dATP. This RNA gel blot reveals a head specific transcript of 4.1 kb. Separate experiments showed that the identified transcript appears to have an onset during late pupal development (data not shown). $F$, Chromosome in situ hybridization with cDNA-83F6. The cDNA was labeled with biotin-dUTP in the process of PCR amplification of the phage cDNA-83F6.1 clone. That probe was then applied to third instar larvae salivary gland polytene chromosomes. The site of hybridization, which is at map position $99 \mathrm{C}$ on the third chromosome, is the reported site of trp (Montell et al., 1985). 
difference was that the mice were immunized for the production of monoclonal antibodies with purified rhabdomeres, not freeze-dried retina. The rhabdomeres from Drosophila compound eyes were purified using a modification of Paulsens's method (Paulsen, 1984) for isolating blowfly rhabdomeres. Freshly excised Drosophila retinas (500-800) were placed in distilled water at $4^{\circ} \mathrm{C}$ and gently dispersed by homogenization. After a brief centrifugation to separate floating debris (trachea, fat, etc.), the remaining, pelleted tissue was resuspended in a $25 \%$ Percoll gradient. Upon centrifugation the rhabdomere bundles formed a broad band in the middle of the gradient and were easily identificd by microscopic inspection of the fractionated gradient. Treatment with EGTA opened the bundles, which were then washed by repeated centrifugation in phosphate-buffered saline to remove some of the highly antigenic extracellular matrix proteins that reside in the intraretinular matrix. The collected rhabdomere bundles were homogenized and injected into a female balb/C mouse with adjuvant on three occasions over a 2 month period. Hybridoma cells were prepared by fusion of mouse myeloma cells to the spleen cells of the immunized mouse. Approximately 250 antibody producing cell lines were tested on cryostat sections of adult head with MAb83F6 being among the cell lines preserved for further study. The monoclonal antibody MAb83F6 was shown to recognize TRP-protein by using the MAb to identify a cDNA expression clone that upon sequencing and mapping to the polytene chromosome showed identity with the previously cloned transient receptor potential gene (Montell and Rubin, 1989; Wong et al., 1989).

Western blot. Normal (WT) adult fly heads were dissected and homogenized in SDS homogenization buffer $(200$ heads $/ 400 \mathrm{ml}$ of $10 \%$ glycerol, $2.3 \%$ SDS, 0.0625 м Tris-HCl pH 6.8, 1 mM PMSF, 5\% betamercaptoethanol). The homogenized tissue was boiled for $10 \mathrm{~min}$ and then spun in microfuge at maximum speed for $15 \mathrm{~min}$. Additional experiments were performed using microsomal and cytosolic fractions of the fly head homogenate. Polyacrylamide gel electrophoresis was performed as previously described (Pollock, et al., 1985). Western transfer was performed on a Polyblot (ABN) semidry blotter with anode buffer $1(0.3 \mathrm{~m}$ Tris, pH $10.4 ; 20 \%$ methanol), anode buffer $2(25 \mathrm{~mm}$ Tris, pH $10.4 ; 20 \%$ methanol) and cathode buffer (25 mM Tris, pH 9.4; 40 mM 6-aminohexanoic acid; $20 \%$ methanol) run at $3 \mathrm{~A}$ (approximately $2.2 \mathrm{~mA} / \mathrm{cm}^{2}$ ), for $40 \mathrm{~min}$. Antigen detection was carried out using the Promega Protoblot alkaline phosphatase staining kit with the primary antibody, ascites fluid of MAb83F6, used at a concentration of 1:600, incubated at room temperature for $1 \mathrm{hr}$.

Molecular biology. The structural gene for the 83F6 antigen was cloned by screening an Oregon-R Drosophila adult head-specific lambda-gt11 expression library (Itoh et al., 1985) following the methods of Sambrook et al. (1989).

DNA purification, isolation of mRNA, Northern blots, chromosome in situ hybridization, and DNA sequencing and analysis were carried out as previously described (Banerjee et al., 1987; Sambrook et al,, 1989; Hyde et al., 1990).

Immunohistochemical staining. Newly emerged adult flies, with wings still folded, were slightly anesthetized with $\mathrm{CO}_{2}$ under bright white light. The whole live fly was immersed in sectioning compound (OCT Compound), and rapidly frozen with dry ice.

The frozen block was equilibrated to a suitable sectioning temperature, $-19^{\circ} \mathrm{C}$ to $-24^{\circ} \mathrm{C}$, depending on the section thickness which varies from $10 \mu \mathrm{m}$ to $1 \mu \mathrm{m}$. The specific localization of MAb83F6 showing "crescents" staining (see below) were only clearly visible when viewed in thin optical section achieved by confocal microscopy or by conventional epifluorescent illumination of thin tissue sections. Serial sections were collected on gelatin subbed slides and immediately immersed in $4 \%$ paraformaldehyde in phosphate buffered saline (PBS) at room temperature. The fixed sections were washed in PBS and presented with primary antibody for $30 \mathrm{~min}$ to $2 \mathrm{hr}$ at room temperature. Primary antibody staining was followed with a wash in PBS and secondary antimouse IgG antibody coupled to Cy3.18 or secondary antibody coupled to fluorescein isothiocyanate (FITC). After a final wash, the tissue sections were cover slipped with PDA-glycerol $(90 \%$ glycerol, $1 \mathrm{mg} / \mathrm{ml}$ $p$-phenylenediamine, $\mathrm{pH}$ to 7.0 with $2 \mathrm{M}$ Tris) to inhibit fading of fluorescence. Tissue sections were imaged with epifluorescent illumination as well as phase contrast or differential interference contrast and photonicrographed onto $35 \mathrm{~mm}$ film.

Overfixation of the tissue dramatically reduces the efficacy of the MAb83F6 staining, reducing the overall intensity of the fluorescence to reveal a general and diffuse stain on the photoreceptor cell. As a control for possible fixation artifacts we analyzed the subcellular localization
Table 1. Relative amounts of TRP protein expression in various strains of Drosophila melanogaster

\begin{tabular}{|c|c|c|c|}
\hline \multirow[b]{2}{*}{ Fly } & \multicolumn{3}{|c|}{ Average relative fluorescence } \\
\hline & $\begin{array}{l}\text { Trial } 1 \\
(n)\end{array}$ & $\begin{array}{l}\text { Trial } 2 \\
(n)\end{array}$ & $\begin{array}{l}\text { Trial } 3 \\
(n)\end{array}$ \\
\hline$c n b w$ & $\begin{array}{l}++ \\
(9)\end{array}$ & $\begin{array}{l}++ \\
(3)\end{array}$ & $\begin{array}{l}++ \\
(5)\end{array}$ \\
\hline$w$ & $\begin{array}{l}++ \\
(7)\end{array}$ & $\begin{array}{c}++ \\
(8)\end{array}$ & $\begin{array}{l}++ \\
(6)\end{array}$ \\
\hline nina $E^{o r a}$ & $\begin{array}{l}++++ \\
(8)\end{array}$ & $\begin{array}{c}+++ \\
(8)\end{array}$ & $\begin{array}{l}+++ \\
(6)\end{array}$ \\
\hline $\operatorname{trp} p^{C M}$ at $19^{\circ} \mathrm{C}$ & + & + & $\begin{array}{l}+ \\
(5)\end{array}$ \\
\hline $\operatorname{trp} p^{C M}$ at $25^{\circ} \mathrm{C}$ & $\begin{array}{l}\text { । } \\
(7)\end{array}$ & $\begin{array}{l}+ \\
(10)\end{array}$ & $\begin{array}{l}+ \\
(4)\end{array}$ \\
\hline $\operatorname{tr} p^{P .301}$ & $\begin{array}{l}- \\
(6)\end{array}$ & ${ }^{-}$ & (5) \\
\hline Blank & not done & - & - \\
\hline
\end{tabular}

of the TRP immunoreactivity with MAb83F6 in two different unfixed tissue preparations. Both whole-mount dissected retina stained in Schnider's insect medium, and unfixed cryosectioned retinas staincd in phosphate-buffered saline revealed abundant immunoreactivity. Although the preservation of the ommatidia structure was not as good as that of the paraformaldehyde fixed sections, rhabdomere bundles could be clearly discerned. In these unfixed tissue preparations, the staining was found to be concentrated near the base of the rhabdomeres, similar to what is seen in the fixed tissue preparation. Because the 83F6 antigen is so sensitive to fixation efforts to use immunoelectron microscopy for the ultrastructural localization of the TRP protein have not been successful.

Measurement of the relative abundance of TRP protein. The relative concentration of the TRP protein in the retina was measured in situ by assaying the relative fluorescence from tissue sections of standard thickness. Independent experimental trials were averaged and normalized to wild type. This was done to minimizc bias duc to lamp variation or variation in the effectiveness of the primary and secondary antibodies. Animals of exactly the same developmental stage (newly eclosed with their wings still folded) were serial sectioned at $7 \mu \mathrm{m}$ thick, with sections taken tangent to the surface of the eye. Each experiment was treated identically using the same dilution of antibody, processing time, etc. The fluorescence measurements were made at approximately the same depth into the retina over a spot area approximately $60 \mu \mathrm{m}$ in diameter. Thus the measurements integrated the fluorescence from approximately 30 facets. Measurement of several independent tissue sections for a given mutant were averaged and compared to wild-type strain, $c n b w$, and white. Since all the sections were the same thickness, the fluorescence measure is from a standard volume and can be directly compared as relative concentrations of the endogenous protein. Because of the inherent differences in microvilli structure between WT and the mutants which may produce different scattering artifacts and thus affect the fluorescence observed, we did not quantitate the differences in fluorescence between WT and the various Drosophila mutants and only gave qualitative values (Table 1).

Electron microscopy. Transmission electron microscopy was performed as described in Ready et al. (1976) and Rubinstein et al. (1989) using a Phillips 300 electron microscope.

\section{Results}

\section{MAb83F6 identified the TRP protein}

Using purified rhabdomeres as an immunogen to generate mouse monoclonal antibodies, we identified a photoreceptor specific antibody MAb83F6 (Fig. 1A,B). Western blot analysis shown in Figure $1 D$, revealed that the antibody identified a single $143 \mathrm{kDa}$ protein found in heads and not detected in bodies. Additional Western analysis showed that the $83 \mathrm{~F} 6$ antigen was associated 
with the microsomal fraction of adult head protein extracts and was not found in cytosol. Two-dimensional gel electrophoresis showed that the antigen is a basic protein with an isoelectric point of nearly 8.0 (data not shown).

We cloned the structural gene for the $83 \mathrm{~F} 6$ antigen by using MAb83F6 to probe an adult head, lambda-gt11 expression library (Itoh et al., 1985). The 83F6-cDNA identified a single transcript of $4.1 \mathrm{~kb}$ in poly $\Lambda^{+} \operatorname{mRN} \Lambda$ purified from adult head, not found in body (Fig. $1 E$ ). The 83 F6-cDNA was cytogenetically mapped to the tip of the third chromosome at position $99 \mathrm{C}$, the same position as the trp mutation (Fig. $1 F$; Montell and Rubin, 1989; Wong et al., 1989). Sequence analysis of the cDNA-83F6.1 revealed identity to the trp-DNA sequence (Montell and Rubin, 1989; Wong et al., 1989). While immunohistochemical analysis with MAb83F 6 on cryosectioned retina from normal flies showed intense staining, the presumably null trp mutants $\left(t r p^{P .34}\right.$ and $\left.t r p^{P .30 \prime}\right)$ lacked staining (Table 1). Previously, Montell and Rubin (1989), showed that no trp mRNA could be detected in extracts of these alleles. Thus, our combined analysis of the 83F6-gene indicated that it corresponds to the transient receptor potential (trp) gene and that MAb83F6 specifically identified the TRP protein.

\section{Analysis of TRP expression in the three visual systems of the fly}

TRP-protein expression was analyzed with MAb83F6 throughout development in the fly. This study revealed intense immunoreactivity in photoreceptors in the adult compound eye and in the adult ocellus (Fig. $1 A, B$ ). We did not detect any antibody staining in the larval photoreceptor organ. Previous studies have shown that different opsin genes are cxpressed in Drosophila adult compound eye and the adult ocellus (Feiler et al., 1988; Pollock and Benzer, 1988). Since the TRP protein is expressed in both compound eye and ocellus, it does not appear that TRPprotein is specific to any particular opsin isoform. Ultrastructurally, however, there are several features found in common between the compound eye and the ocellus that are not apparent in the larval photoreceptor (Pollock and Benzer, 1988; Slark et al., 1989). In particular, the structure and organization of the rhabdomeric microvilli and the subrhabdomeric cysternae is quite similar between the two adult visual organs where true rod-like rhabdomeres are formed. However, there are no true rod-like rhabdomeres apparent in the larval photoreceptor, rather a simple, primitive elaboration of membranes and cisternae (Pollock and Benzer, 1988). Thus, the lack of TRP-protein staining in the larval photoreceptor and the lack of overt, interdigitating spaces between the membrane elaboration may indicate that the larval photoreceptor organs function differently from the adult photoreceptors.

In the adult compound eye, the sensitivity of the staining with MAb83F6 combined with long photographic exposure revealed immunoreactivity of MAb83F6 in photoreceptor cell axons projecting from the retina to the lamina and the medulla (Fig. 1A). These observations raise the possibility that the trp-protein is involved with controlling the influx of calcium both in the cell body in response to light and at the synapse in response to the depolarizing receptor potential. Further studies will be needed to support this speculation.

TRP is localized to the base of the microvilli in normal retina

Figure 2 shows high magnification light micrographs of a normal ommatidia viewed in cross section after immunofluorescent staining with the anti-TRP monoclonal antibody (MAb83F6). The "crescents" of fluorescent staining make an arrangement like seven flower petals corresponding to the seven photoreceptor cells seen in any cross-sectional plane. In the normal retina, MAb83F6 specifically identifies an intense band of immunoreactivity located at the base of the rhabdomeres near the submicrovilli cisternae (SMC). Figure $2 A$ shows the TRP protein revealed with epifluorescent illumination of MAb83F6 as well as the rhabdomeric bundle revealed with phase contrast illumination. A second example of this pattern of staining, shown in Figure $2 B$ with epifluorescent illumination alone. This image clearly shows that the TRP staining is primarily localized to the base of the microvilli and not across the entire cross section of the rhabdomere.

The main structural features of an ommatidial facet and an individual cell are detailed in Figure 2, $C$ and $D$. This cartoon highlights the microvilli, the loop of plasma membrane at the base of the rhabdomere, and the adjacent smooth endoplasmic reticulum located nearby. The smooth endoplasmic reticulum is a submicrovilli cisternae (SMC), which has been shown to contain calcium in the fly (Walz, 1982) and to release $\mathrm{Ca}^{2+}$ upon application of InsP $_{3}$ in the bee photoreceptors (Baumann and Walz, 1989). The region of the cell where TRP protein is found is highlighted in Figure 2, $C$ and $D$. This region of the cell includes both the SMC as well as the plasma membrane loops at the base of the rhabdomeres (arrows).

\section{Mislocalization of TRP in trp mutant strains}

We applied MAb83F6 to the original allele of $t r p, \operatorname{trp}^{c M}$ (Cosens and Manning, 1969). This allele has been shown to be developmental temperature sensitive, such that when raiscd at $19^{\circ} \mathrm{C}$ the electrophysiological phenotype is more similar to that of wild type as compared to mutant raised at $25^{\circ} \mathrm{C}$ (Minke, 1983; also see Wong et al., 1989 for similar phenomenon for allele, $\left.\operatorname{tr} p^{P 3 / 3}\right)$. Unlike $t r p^{P .301}$ or $t r p^{P 34.3}$, some level of $\operatorname{trp}$ mRNA can be observed in $\operatorname{trp}^{C M}$ (Montell and Rubin, 1989) though overall there is less TRP protein evident in $\operatorname{trp}^{C M}$ than WT (Table 1). Figure 3 shows that the localization of the TRP protein in $t r p^{C M}$ at the two different rearing temperatures is different. At $18^{\circ} \mathrm{C}$ (Fig. $3 A$ ) the protein localization is slightly more restricted (see intense staining) relative to $\operatorname{trp}^{C M}$ raised at $25^{\circ} \mathrm{C}$ (Fig. $3 B$ ). In both the TRP protein is found throughout the whole cell and not only at the base of the microvilli. This is in sharp contrast to the localization seen in wild-type flies, shown in Figure $3 D$ with similar presentation conditions. Interestingly, in $\operatorname{trp} p^{C M}$ retina raised at either $19^{\circ} \mathrm{C}$ or $25^{\circ} \mathrm{C}$ a significant amount of TRP staining appears in the main body of the cell. These data suggest that $\operatorname{trp}^{C M}$ may be defective in a manner that prevents processing, folding or insertion into its functional location, presumably the surface membrane (see functional confirmation below). Our analysis of the fluorescence intensity (see Materials and Methods) summarized in Table 1, suggests that, the $\operatorname{trp}^{C M}$ mutant produces less TRP protein than that found in normal retina. By contrast the level of immunofluorescence in the presumably null allele, $\operatorname{tr} p^{P 30 l}$, was much reduced and was not significantly higher than background autofluorescence (Fig. 3C). Western blot analysis revealed complete absence of the TRP protein in $\operatorname{tr} p^{P 30 I}$ mutant (Montell and Rubin, 1989).

\section{TRP localization in the ninaE $\mathrm{E}^{\text {ora }}$ mutant}

Another Drosophila mutant useful to our TRP localization study is ninaE ${ }^{o r a}$. The ninaE gene has been shown to encode the opsin 

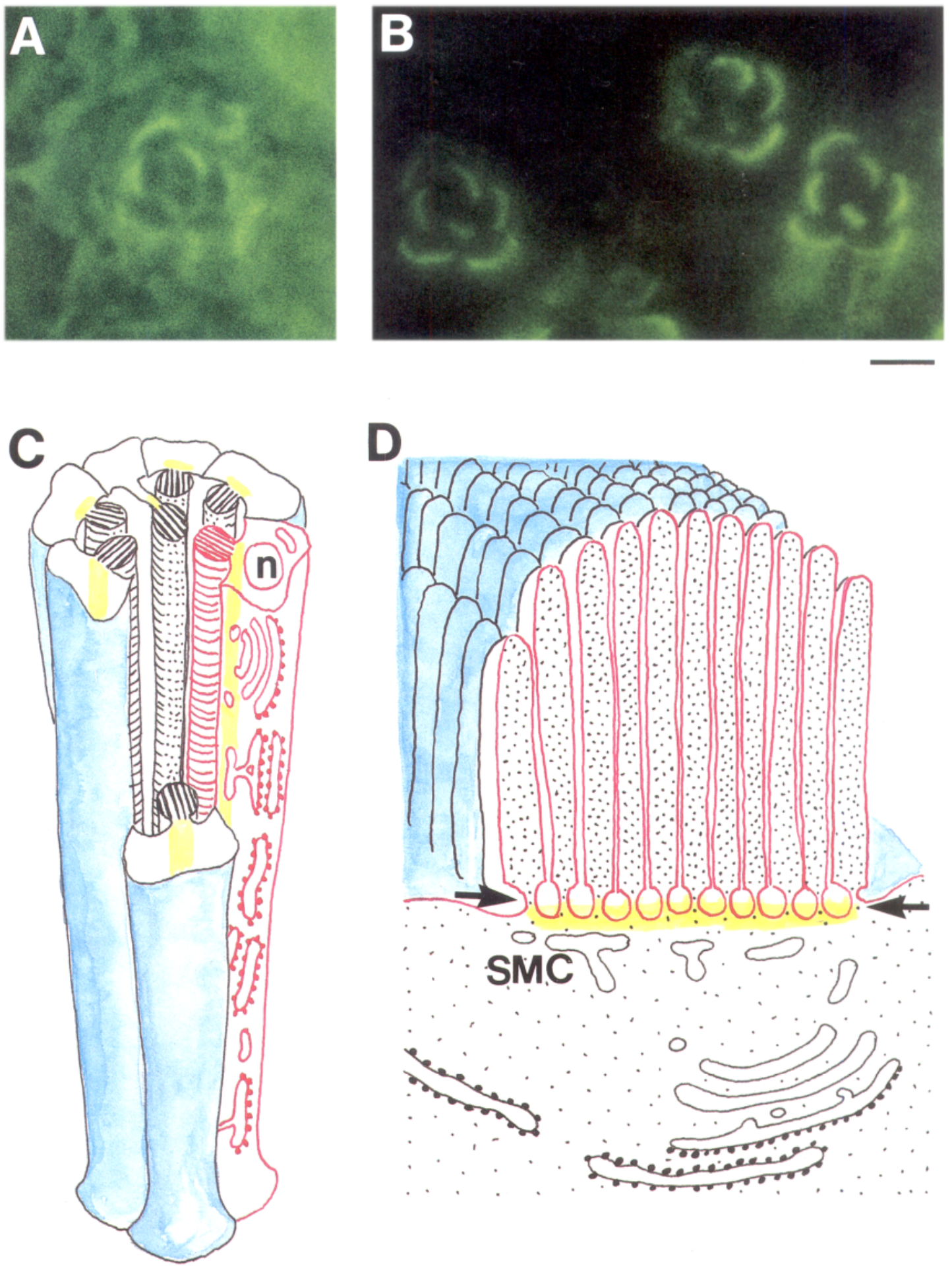

D

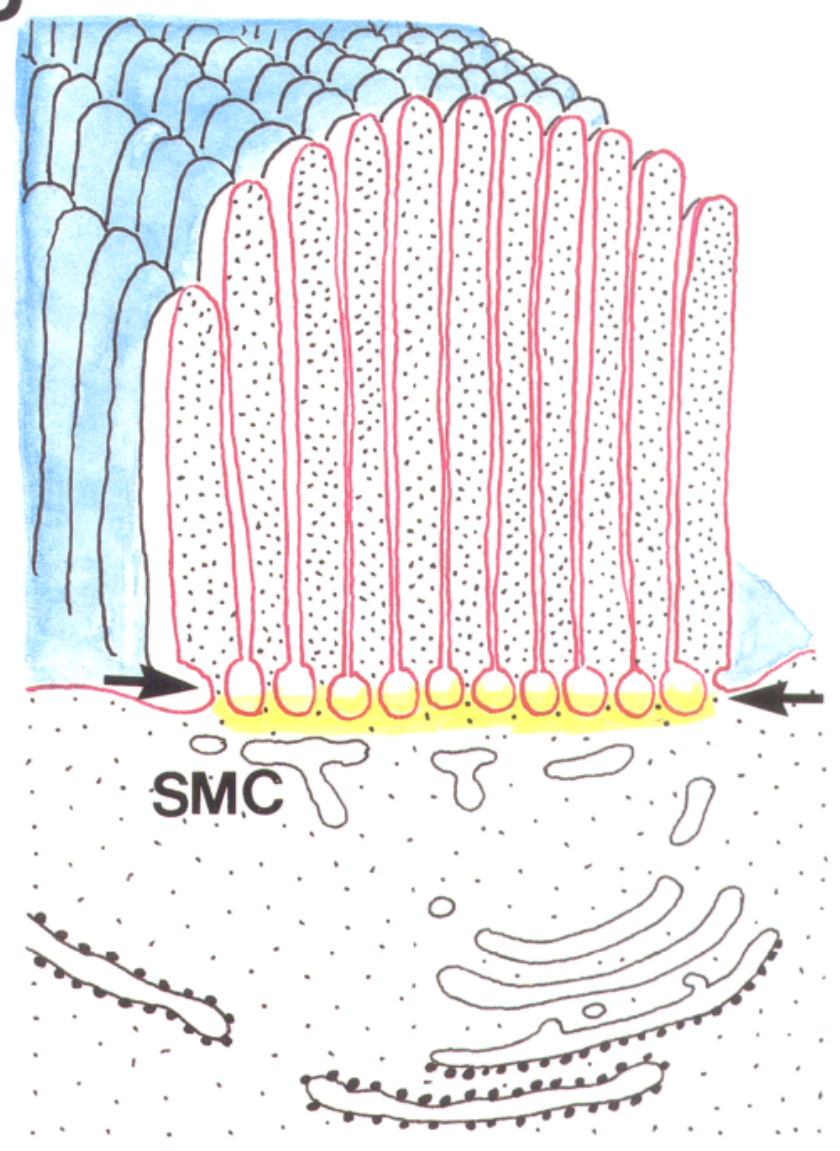

Figure 2. TRP protein is subcellularly localized as a ribbon found at the base of the rhabdomere. $A$, TRP protein is found at the base of the normal rhabdomeres of $c n b w$. Epifluorescent illumination of FITC stained MAb83F6 reveals crescents of staining. In this image, the phase illumination was included to high-lighting the dark spots of the seven rhabdomere bundles. The resolution of this image relies on the thin tissue section, approximately $2 \mu \mathrm{m}$ thick. $B$, A second example of the FITC stained MAb83F6 crescents viewed in a 1-2 $\mu \mathrm{m}$ thick cryosection of $c n$ bw. This image shows a field of view that includes more than three adjacent facets. Scale bar for $A$ and $B$ indicates $3 \mu \mathrm{m}$. $C$, A cartoon demonstrating the basic structure of an ommatidial facet, revealing the photoreceptor cells seen in cross section, similar to the field of view shown in $A$ and $B$. The yellow-green ribbon detected in each photoreceptor cell represents the expression pattern seen for TRP protein throughout the retina. $n$ is the nucleus. $D$, A cartoon shows an enlarged view of the primary structures found near the base of the rhabdomere in a photoreceptor cell. The red plasma membrane of the microvilli which form the rhabdomere is highlighted with the yellow-green dye at the proposed functional localization of the TRP protein (arrow). Just below the surface of the layer of plasma membrane loops located at the base of the rhabdomere one can find a smooth endoplasmic reticulum, a $\mathrm{Ca}^{2+}$ cisternae called the submicrovillar cisternae $(S M C)$. 


\section{$\operatorname{trp}^{C M} @ 18^{\circ} \mathrm{C}$}

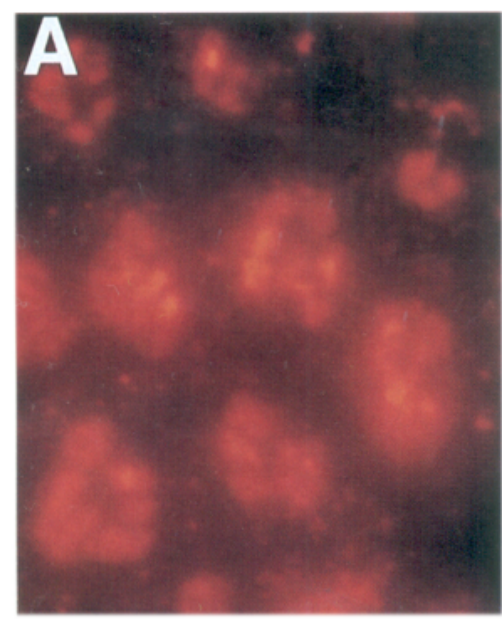

Wild Type(cnbw)

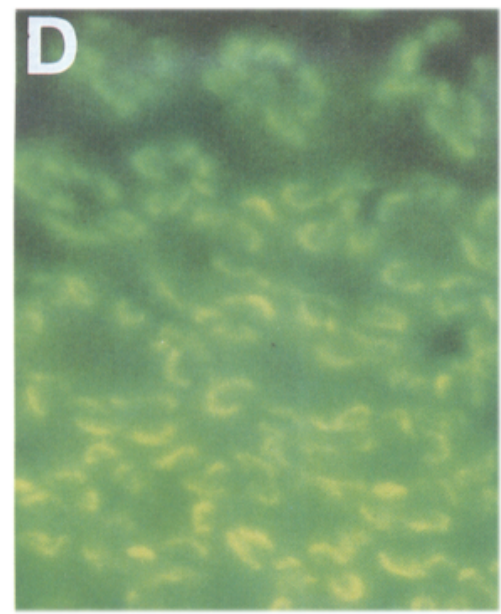

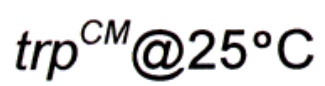

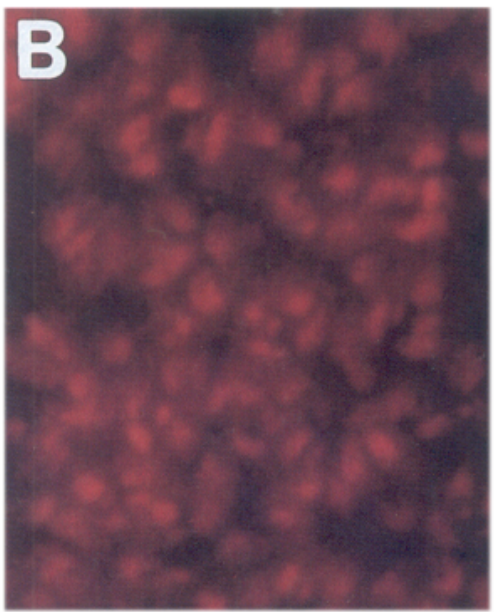

ninaE

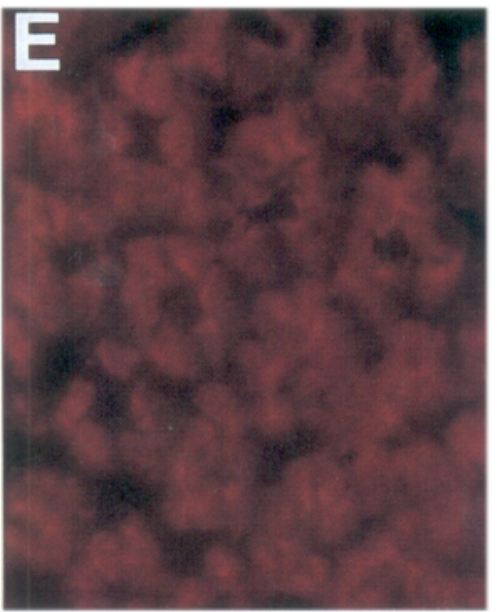

$\operatorname{trp} p^{P 301}$

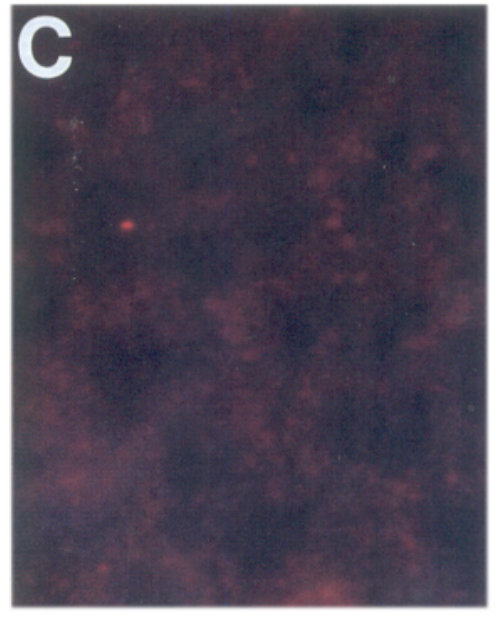

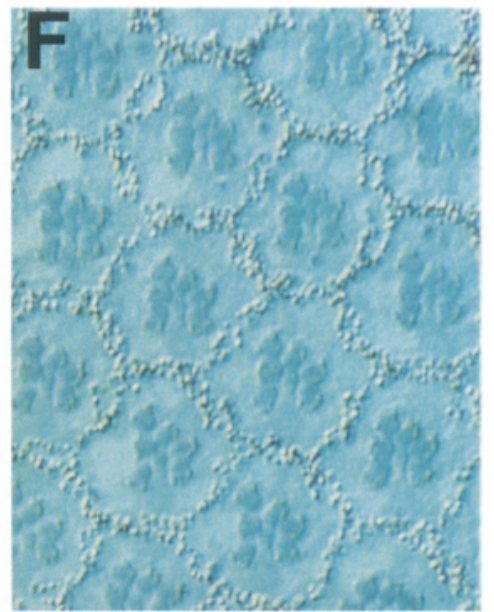

Figure 3. Comparison of TRP expression in mutant eyes. All images are taken at the same magnification, of thin (1-3 $\mu \mathrm{m})$ sections cut from identically staged, newly emerged flies. $A$, Epifluorescent illumination of the Cy3-labeled TRP protein found in $\operatorname{trp}{ }^{C M}$ reared at $18^{\circ} \mathrm{C}$. Though the expression is more diffuse than that seen in the normal retina, comparison with a $\operatorname{trp}{ }^{C M}$ reared at $25^{\circ} \mathrm{C}$ shows sharper localization. Nonetheless, this mutant does not localize the protein as tightly as does the normal retina (see $D$ ). $B$, Epifluorescent illumination of the Cy3-labeled TRP protein found in $\operatorname{trp}^{\mathrm{CM}}$ reared at $25^{\circ} \mathrm{C}$. This expression pattern demonstrates the fully mutant distribution, with immunofluorescence evident throughout the cell cytoplasm. $C$, Epifluorescent illumination of the Cy3-labeled MAb83F6 reveals the background nonspecific fluorescence found in $t^{p} p^{p: 30 t}$ protein null. Even this micrograph is slightly over exposed to demonstrate auto fluorescence. Detailed in Table 1, the $\operatorname{trp}^{P 30 t}$ mutant produces significantly less fluorescence than the normal MAb83F6 stained retina. $D$, Epifluorescent illumination of the FITC-labeled TRP protein found in normal ( $c n$ $b w)$. FITC was used as a stain here to photographically distinguish the normal pattern of expression from the mutant patterns. At this magnification, the staining is evident as tight little crescents, associated with each photoreceptor cell and rhabdomere profiles. E, Epifluorescent illumination of the Cy3-labeled TRP protein found in ninaE mutant retina. The stain is reminiscent of the tight crescents detected in the normal retina. Not evident in this photographic reproduction is the fact that the staining in the ninaE mutant retina is more intense as that seen in the normal retina (see Table 1). $F$, Normal pigmented eye (Oregon-R) structure is revealed in a bright-field photomicrograph, toluidine blue stain of a $1 \mu \mathrm{m}$ plastic section. Taken at the same magnification as the epifluorescent pictures, this image reveals the gross anatomy of the fly eye. The seven dark stained spots seen in each profile are the cross sections of the photoreceptor rhabdomeres. Large pigment granules found in the pigment cells optically isolate each facet from its neighbor. Scale bar, $15 \mu \mathrm{m}$ for $A-F$.

protein, Rh1, expressed in photoreceptor cells R1-R6 (O'Tousa et al., 1985; Zuker et al., 1985; Pollock and Benzer, 1988). The ninaE ${ }^{\text {ora }}$ allele has no light-dependent receptor potential in R1R6 cells (Harris et al., 1976; O'Tousa et al., 1989). Also, the length of its microvilli is highly reduced with age (Schinz et al., 1982; Stark and Sapp, 1987; O'Tousa et al., 1989; Leonard et al., 1992) until the microvilli completely disappear early in adult life (Harris et al., 1976; Stark and Sapp, 1987; O'Tousa et al., 1989; Leonard et al., 1992). Light microscopic immunostaining of TRP protein with MAb83F6 in ninaE ${ }^{\text {ora }}$ is shown in Figure $3 E$. Even though the rhabdomere morphology is altered, intense crescent-like TRP staining was seen, though not as sharply de- 
fined as that found in the normal eye (Fig. 3D). Interestingly, analysis of immunofluorescence in nina $E^{o r a}$ retinae suggests that considerably more TRP protein is expressed than in wild type (Table 1).

Using electron microscopy, Figure 4 compares the cross section of ninaE $E^{o r i}$ ommatidia of a newly emerged fly ( $<3 \mathrm{hr}$ ) (Fig. $4 A$ ), to the ommatidia of a normal fly (Fig. $4 B$ ). Confirming the earlier studies, in ninaE ${ }^{\text {ora }}$, the microvilli of R1-R6 cells (but not R7) are significantly shorter relative to wild type (Stark and Sapp, 1987; Schinz et al., 1982; O’Tousa et al., 1989; Leonard et al., 1992). Furthermore, electron microscopy revealed two features that may be correlated with the increased expression of TRP protein in nina $E^{m a}$ at specific area. First, the number of microvilli in a given cross section of R1-R6 rhabdomeres was significantly increased relative to wild type (for a quantitative study see below) and secondly the electron micrograph showed that the loops of plasma membrane at the base of the rhabdomere were increased in diameter (arrow) as compared to both WT and trp mutants. This increase in diameter of the plasma membrane loops was found in all 16 nina $E^{u r a}$ flies used for this EM study.

\section{Functional localization of TRP using TRP-dependent rundown current}

The immunohistochemical staining of TRP in WT strongly suggests that TRP is mainly localized to the base rather then the entire length of the microvilli. However, the immunohistochemical staining in the $\operatorname{trp}^{c M}$ allele indicated that not all the TRP protein that stains is necessarily functional. In an attempt to find independent support for the immunolocalization with respect to functional TRP protein we attempted to measure the magnitude of trp-dependent channel activity under experimental conditions in which the microvillar area was reduced by mutation. For this purpose we used the ninaEra mutant in which the microvillar area of R1-R6 cells decreases gradually with age (see below). Since this mutant produces no response to light in R1-R6 cells, in order to provide a quantitative measure of functional channel expression we exploited a phenomenon whereby the light-sensitive channels activate spontaneously during prolonged wholecell recording (see "rundown current" and Fig. 6 below). Before describing these results, however, we first present evidence showing that this measure is indeed a sensitive indicator of functional TRP protein levels.

\section{Functional expression of TRP protein in $\operatorname{tr}^{\mathrm{CM}}$}

The immunohistochemical staining of TRP in the developmental-temperature-sensitive allele of $\operatorname{trp}\left(\operatorname{trp} p^{C M}\right)$ showed that the localization of TRP in $t r p^{C M}$ ratsed at two different temperatures $\left(18^{\circ} \mathrm{C}, 25^{\circ} \mathrm{C}\right.$ ) is distinctly different (Fig. 3). To test whether this has a functional consequence we examined the reversal potential $\left(E_{r e v}\right)$ of the light-induced current in $\operatorname{trp}^{C M}$ raised at $19^{\circ} \mathrm{C}$ and $25^{\circ} \mathrm{C}$. To maximize the possibility of detecting the contribution of the $\mathrm{Ca}^{2+}$ selective trp-dependent channels, measurements were made with $10 \mathrm{mM} \mathrm{Ca}^{2+}$ in the extracellular Ringer's.

Figure $5 A$ shows the reversal potential $\left(E_{\mathrm{rcv}}\right)$ of the light-induced current of $\operatorname{trp} p^{C M}$ raised at $19^{\circ} \mathrm{C}$ and $25^{\circ} \mathrm{C}$. Compared to wild type ( $E_{r e v}$ of about $20 \mathrm{mV}$; Hardie and Minke, 1992), $E_{\text {rev }}$ of the trp mutant is much smaller, when measured at the same level of external $\mathrm{Ca}^{2+}$, under both rearing conditions. In ommatidia of $\operatorname{trp}^{C M}$ files raised at $25^{\circ} \mathrm{C} E_{\text {rev }}$ was $0.1 \pm 0.7 \mathrm{mV}$ $(\mathrm{SEM} ; n=9)$ while in $t r p^{C M}$ flies raised at $19^{\circ} \mathrm{C} E_{\mathrm{rev}}$ was $8.0 \pm$ $1.5 \mathrm{mV}(n=6)$. This $8 \mathrm{mV}$ difference in $E_{r e v}$ is highly statistically significant $(P<0.001$ Student's $t)$ and presumably indi- cates the expression of significant levels of functional $\mathrm{Ca}^{2+}$ selective trp-dependent channels. Figure $5 B$ shows the results of identical experimental protocols to that of Figure $5 A$ except that the supposedly null allele of $\operatorname{trp}\left(\operatorname{tr} p^{P 30 \prime}\right)$ was used. No significant effect of the developmental temperature on $E_{r e v}$ was found in this allele $\left(E_{\mathrm{rcv}}=0.9 \pm 0.6 \mathrm{mV}, n=11\right.$ in flies reared at $25^{\circ} \mathrm{C}$, and $0.5 \pm 0.6 \mathrm{mV} n=13$ at $19^{\circ} \mathrm{C}$ ). These results indicate that $E_{r e v}$ is a sensitive parameter that is influenced by the amount of functional TRP and that the $\operatorname{trp}^{C M}$ allele does produce some functional TRP protein when reared at $19^{\circ} \mathrm{C}$, but probably none when reared at $25^{\circ} \mathrm{C}$. Measurements of the rundown current support this conclusion (Table 2; see details below).

\section{Functional TRP is required for production of rundown current}

Within a few minutes of establishing the whole-cell recordings configuration in isolated ommatidia of Drosophila the sensitivity to light of the photoreceptor runs down and an epiphenomenon manifested as a conspicuous inward current develops spontaneously (Hardie and Minke, 1994a,b; Fig. 6A). This rundown current (RDC) reflects spontaneous activation of a major proportion of the cell's complement of light sensitive channels. The RDC is blocked by $\mathrm{La}^{3+}$ and the trp mutation (Hardie and Minke $1994 \mathrm{a}$ and see below) indicating that TRP is required for producing the RDC. Once initiated, the RDC is apparently produced by both trp and non-trp-dependent channels, but with a dominant contribution from the trp-dependent channels (Hardie and Minke, 1994a,b and see Table 2 described below).

Figure $6 A$ (left) shows an example of the RDC in a wild-type photorcceptor clamped at $60 \mathrm{mV}$. This RDC followed a characteristic time course and magnitude that increased over a period of several seconds. It reached a peak, occasionally followed by oscillations (in $<10 \%$ of wild-type photoreceptors and $>40 \%$ in the ninaEra mutant). The current then relaxed to a noisy steady state level that lasted many minutes (see Hardie and Minke $1994 \mathrm{a}, \mathrm{b}$, for details). When measured in normal external $\mathrm{Ca}^{2+}$ (1.5 ImM), the RDC was accompanied by a huge influx of $\mathrm{Ca}^{2}$ (as evidenced by $\mathrm{Ca}^{2+}$ indicator dyes, not shown), which in turn inactivated the trp dependent channels (Fig. $6 C$; see also Hardie and Minke, 1994b). To measure the magnitude of the RDC without inactivation, after development of the RDC we replaced the external solution with $\mathrm{Ca}^{2+}$ free Ringer's solution (no added $\mathrm{Ca}^{2+}, 100 \mu \mathrm{M}$ EGTA) and applied short voltage steps which clamped the membrane voltage to various potentials. The resulting currents were used to estimate the RDC without the interference of inactivation (Fig. 6D).

To demonstrate that the amplitude of RDC is dependent on the amount of functional TRP protein we varied the amount of TRP by changing the developmental temperature and monitored the amplitude of RDC at $-60 \mathrm{mV}$ holding potential in zero external $\mathrm{Ca}^{2+}$. In $\operatorname{trp}^{\mathrm{CM}}$ (adult) raised at $19^{\circ} \mathrm{C}$ the amplitude of the RDC was much smaller relative to WT. Table 2 (top) shows that the $R D C$ in $t r p^{C M}$ raised at $19^{\circ} \mathrm{C}$ was $41 \%$ relative to $W T$. In $\operatorname{trp}{ }^{C M}$ raised at $24^{\circ} \mathrm{C}$ the amplitude of the RDC could not be measured because only one out of 17 flies produced a small $(0.52 \mathrm{nA}) \mathrm{RDC}$. We also modulated the amount of functional TRP by varying $t r p^{+}$dosage. Since $t r p^{P 301}$ is apparently a null allele, we examined the effect of $t r p^{+}$dosage on the RDC in $t r p^{P 301} / \mathrm{trp}^{P 301}$, in $t r p^{P .301} / \mathrm{trp}^{+}$, and in $t r p^{+} / \mathrm{trp}^{+}$. If the RDC is dominated by the activity of TRP-dependent channels, it is expected that the amplitude of the RDC will be reduced with the reduction in rrp $^{+}$copies. Table 2 (bottom) shows that this expectation was fulfilled. The averaged amplitude of the RDC (at zero external 

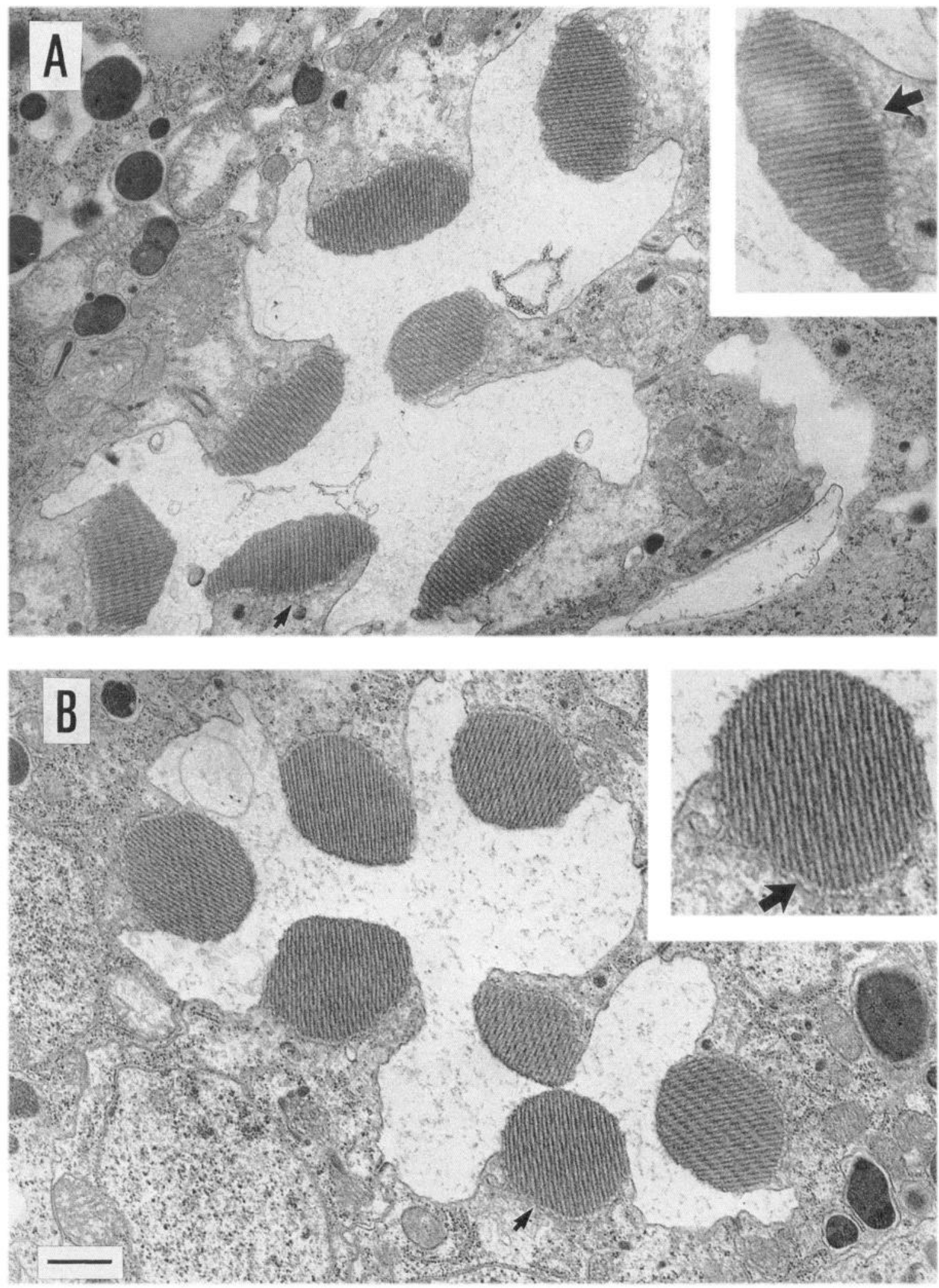

Figure 4. Ultrastructural comparison of ninaE $E^{\text {ora }}$ and a normal rhabdomere. $A$, Cross section of a single ommatidium of ninaE $E^{\text {ora }}(1 \mathrm{~d}$ old $)$ and of a single rhabdomere (inset). The length of the microvilli is reduced relative to WT $(B)$ while the number of microvilli increases. Also, enlargement of the loops at the base of the microvilli can be seen in several regions in ninaEra (arrow) but not in WT. B, Cross section of an ommatidium of wild type $(1 \mathrm{~d}$ old $)$. The typical structure of fly ommatidium with seven rhabdomeres is shown. The inset shows an enlarged view of a single rhabdomere. The figure snows an example of normal appearing ommatidium. Scale bar: $1 \mu \mathrm{m}$ for $A$ and $B ; 0.57 \mu \mathrm{m}$ for insets. 


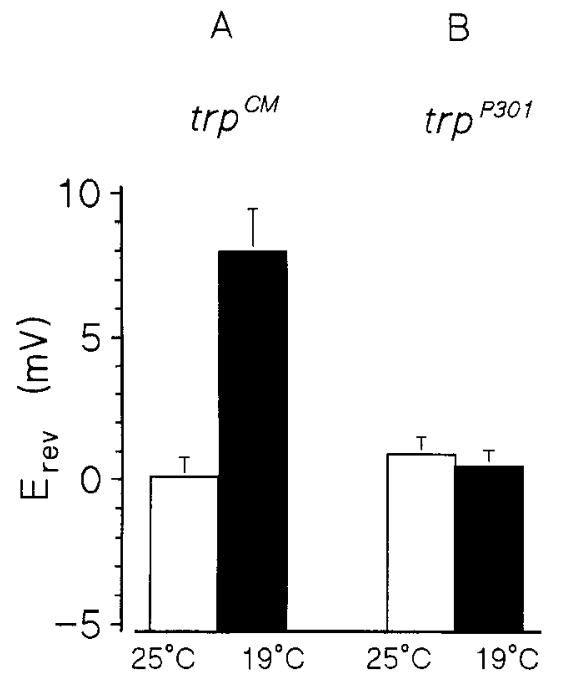

Figure 5. The reversal potential $\left(E_{\mathrm{rvv}}\right)$ and RDC depends on developmental temperature in the $\operatorname{tr} p^{C M}$ allele. $A$ and $B$, Reversal potentials of $\operatorname{trp}^{C M}(A)$ and $\operatorname{trp}{ }^{p .30 I}(B)$ measured in $10 \mathrm{mM} \mathrm{Ca}^{2+}$ Ringer's for flies raised at $19^{\circ} \mathrm{C}$ and $25^{\circ} \mathrm{C}$. For $t r p^{C M}$ there is a significant difference in $E_{\text {rev }}$ in flies raised at $19^{\circ} \mathrm{C}$ and $25^{\circ} \mathrm{C}$, with $E_{\text {rev }}$ being more negative in flies raised at $25^{\circ} \mathrm{C}$, indicating reduced expression of TRP at that temperature. In $t r p^{p .30 t}$ there is no effect of developmental temperature on $E_{\text {rev }}$ consistent with $t r p^{p 30 \prime}$ being a null $t r p$ mutant. Values are means \pm SEM from between 6 and 13 cells for each data point (see text).

$\mathrm{Ca}^{2+} ;-60 \mathrm{mV}$ ) was $67 \%$ in $t r p^{P 30 /} / \mathrm{trp}^{+}$relative to $\mathrm{trp}^{+} / \mathrm{trp}^{+}$. In $t r p^{P 30 I} / \operatorname{trp}^{P .301}$ the amplitude of the RDC could not be measured since only one out of 17 files produced a small (0.46 nA) RDC. These results thus indicated that functional TRP protein is required for RDC production and that the amplitude of the RDC depends on the amount of functional TRP.

Measurements of whole-cell capacitance and RDC as a function of age in wild type and ninaE ${ }^{\text {ora }}$

Having established the RDC as a sensitive indicator of functional TRP expression, we are now in a position to compare the magnitude of the RDC with the microvillar membrane area in both WT and the opsin null mutation nina $E^{\text {ora }}$. As a measure of microvillar area we used the whole-cell capacitance. Although

Table 2. The effect of developmental temperature and trp $^{+}$ dosage on rundown current (RDC)

Fly

RDC (nA)

\section{Developmental temperature}

\begin{tabular}{|c|c|}
\hline $\begin{array}{c}t r p^{C M} / t r p^{C M} \\
\left(24^{\circ} \mathrm{C}\right)\end{array}$ & — $^{a}$ \\
\hline $\operatorname{trp} p^{C M /} / t r p^{C M}$ & $0.73 \perp 0.07^{* *}$ \\
\hline$\left(19^{\circ} \mathrm{C}\right)$ & $(n=9)$ \\
\hline$t r p^{+} / t r p^{+}(\mathrm{WT})$ & $\begin{array}{l}1.8 \pm 0.16^{* *} \\
(n=7)\end{array}$ \\
\hline \multicolumn{2}{|l|}{$p^{+}$dosage } \\
\hline $\operatorname{tr} p^{P 301} / \operatorname{tr} p^{P 301}$ & $-^{a}$ \\
\hline$t r p^{P 301} / t r p^{+}$ & $\begin{array}{l}1.2 \pm 0.08^{* *} \\
(n=5)\end{array}$ \\
\hline
\end{tabular}

Data are presented \pm SEM.

"One of 17 flies gave a small RDC.

$* * 5 \%$ significance in $t$ test.

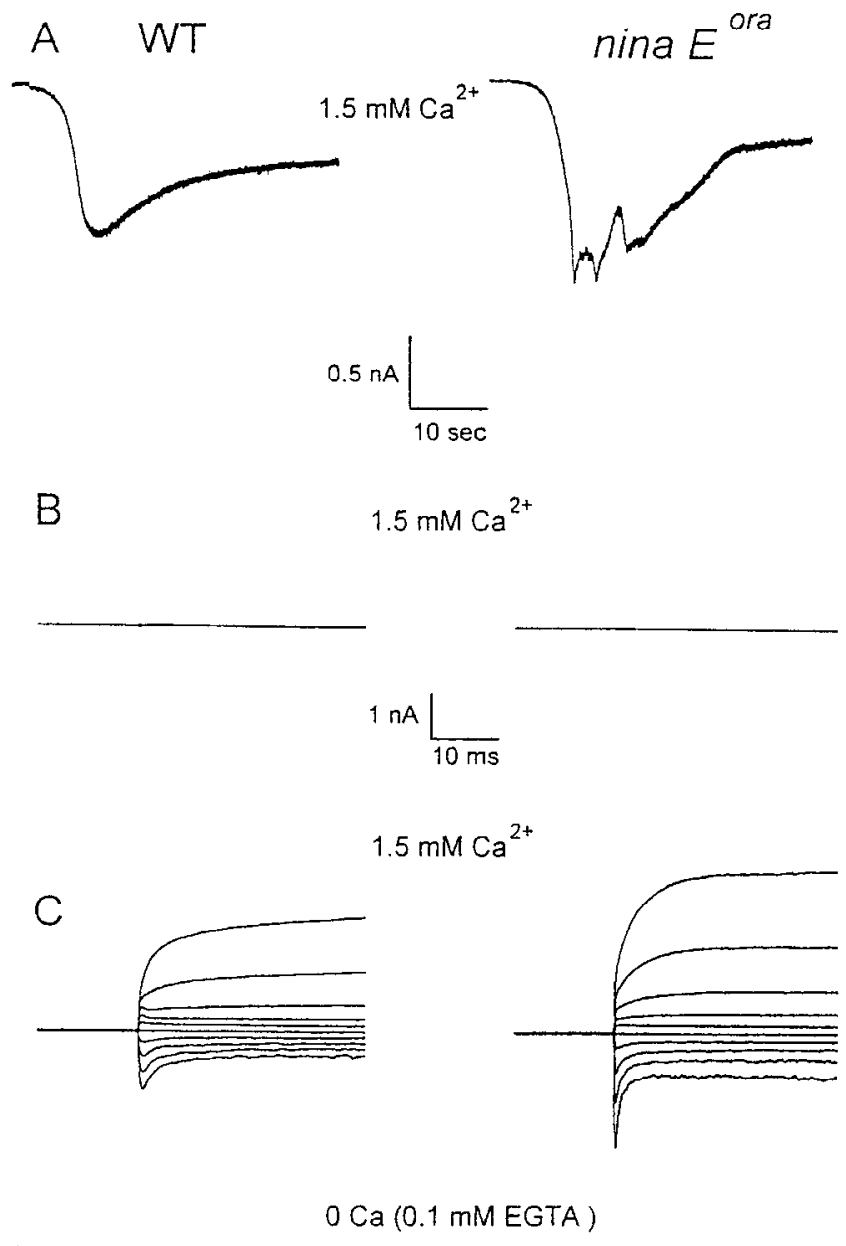

$\mathrm{D}$
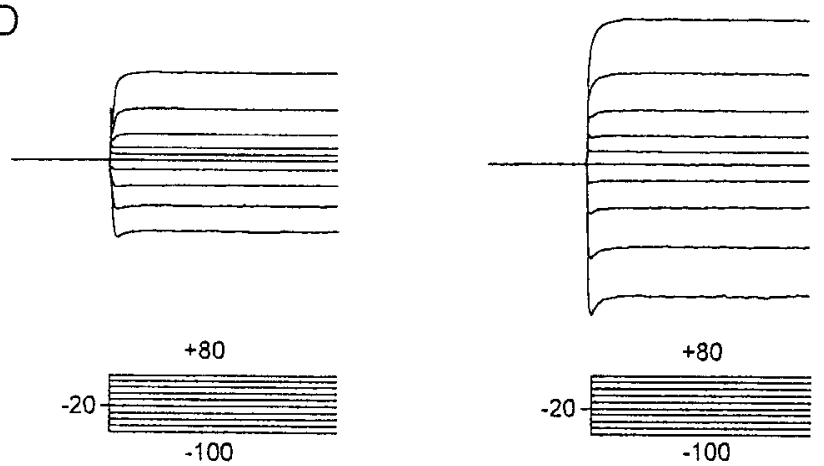

Figure 6. $\mathrm{Ca}^{2+}$ and voltage dependence of rundown currents (RDCs) in adult wild type (left) and nina $E^{\text {ora }}$ (right). $A$, Spontaneous development of RDCs recorded 3 min after establishing whole-cell recording configuration. $B$ and $C$, Currents elicited by $50 \mathrm{msec}$ voltage steps ( +80 to $-100 \mathrm{mV}$ ) applied before $(B)$ and 2 min after RDC formation $(C)$ from a holding potential of $-20 \mathrm{mV}$ in $1.5 \mathrm{~mm} \mathrm{Ca} \mathrm{Ca}^{2+}$ Ringer's using Cs/TEA Cl-based electrode solution. $D$, Virtually no dynamic behavior is seen in zero $\mathrm{Ca}^{2+}$ Ringer's (no $\mathrm{Ca}^{2+}$ added +0.1 mM EGTA), although the currents reveal a characteristic inward and outward rectification (see Fig. 8). Traces $A$ were filtered at $2 \mathrm{kHz}$ and sampled at $1 \mathrm{kHz}$. Traces $B \sim D$ were filtered at $5 \mathrm{kHz}$ and sampled at $10 \mathrm{kHz}$. Traces have not been leak subtracted, however, series resistance was carefully compensated for.

this provides a measure of the entire membrane surface, area ca. $80 \%$ of the plasma membrane area in adults derives from the microvilli. The validity of this approach has been demonstrated in a detailed study of the development of the pupal photorecep- 


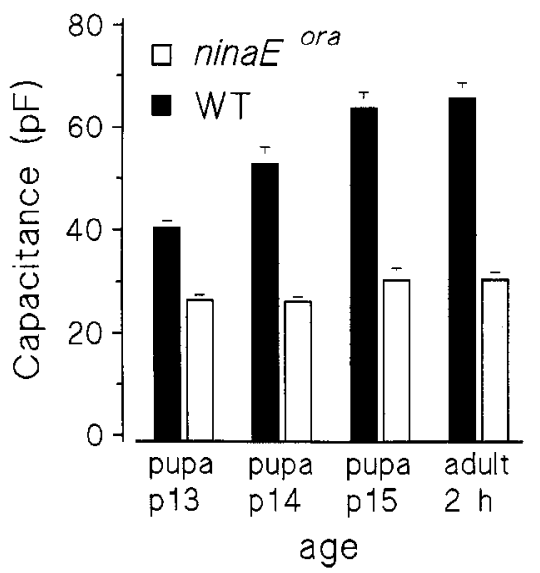

Figure 7. Development of whole-cell capacitance with age in wild type and nina $E^{\text {ora }}$. Photoreceptors reach their maximal length by about $80 \mathrm{hr}$ (early P14) post puparium formation. Most of the increase in capacitance after P14 can be attributed to growth of the microvilli and an increase in their number in cross section. In wild type the capacitance reached saturation at about $97 \mathrm{hr}$ (P15). In ninaE ${ }^{\text {ora }}$ the capacitance remains relatively small throughout development consistent with the shorter microvilli revealed in EM cross sections (Fig. 4). The female flies used for this study hatched at about $100 \mathrm{hr}$ post puparium formation $\left(25^{\circ} \mathrm{C}\right) ; 9-16$ cells were used for each experimental condition. The error bars are SEM.

tor where a large increase in cell capacitance was shown between stage P14 and adult (Hardie et al., 1993). Since photoreceptor length and diameter hardly change beyond P14 this increase in capacitance can almost entirely be attributed to the increase in microvillar length (and number) that occurs during this period. Figure 7 compares the whole-cell capacitance of WT and ninaEra as a function of pupal age, measurements only being taken from ommatidia of similar length so that any differences should reflect the contribution of the microvilli. As previously described (Hardie et al., 1993), in WT ommatidia there is an increase in whole-cell capacitance between stages P13 and P15 which almost reached saturation at P15. At P13 the photoreceptors have not yet reached full length and also there is still no light response in the photoreceptors. Nevertheless, there are already TRP-dependent channels at P13 as evidenced by the production of RDC. In ninaE ${ }^{\text {ora }}$, the whole-cell capacitance is significantly smaller relative to WT at all developmental stages. This difference increased with pupal age because the whole-cell capacitance in the mutant remained approximately constant while that of WT increased with age. At P15 or in adult the whole-cell capacitance of WT photoreceptors (and hence of microvillar area) is more than twice as large as that in ninaEra.

Two minutes after the initiation of RDC, a series of voltage steps (from $-100 \mathrm{mV}$ to $+80 \mathrm{mV}$ in $20 \mathrm{mV}$ steps) were applied at normal (1.5 $\mathrm{mm} \mathrm{Ca}{ }^{2+}$ ) Ringer's solution (Fig. $6 C$ ). Then, Ringer's solution without $\mathrm{Ca}^{2+}(100 \mu \mathrm{M}$ EGTA) was applied and 3 min later the series of voltage steps was applied again (Fig. $6 D)$. The current-voltage relationship ( $I-V$ curve) under zero $\mathrm{Ca}^{2+}$ was plotted (Fig. 8). Similar experiments were carried out for the developmental stages P13, P14, P15, and 2 hr old adult wild-type and ninaEra flies. Averages of the data point of $I-V$ curves are presented in Figure $8 A-D$. These $I-V$ curves are typical for the trp-dependent current showing both inward and outward rectification at negative and positive membrane voltages respectively (Hardie and Minke, 1994a,b). The $I-V$ curves show that in both wild type and ninaE ${ }^{\text {ora }}$ the magnitude of the RDC
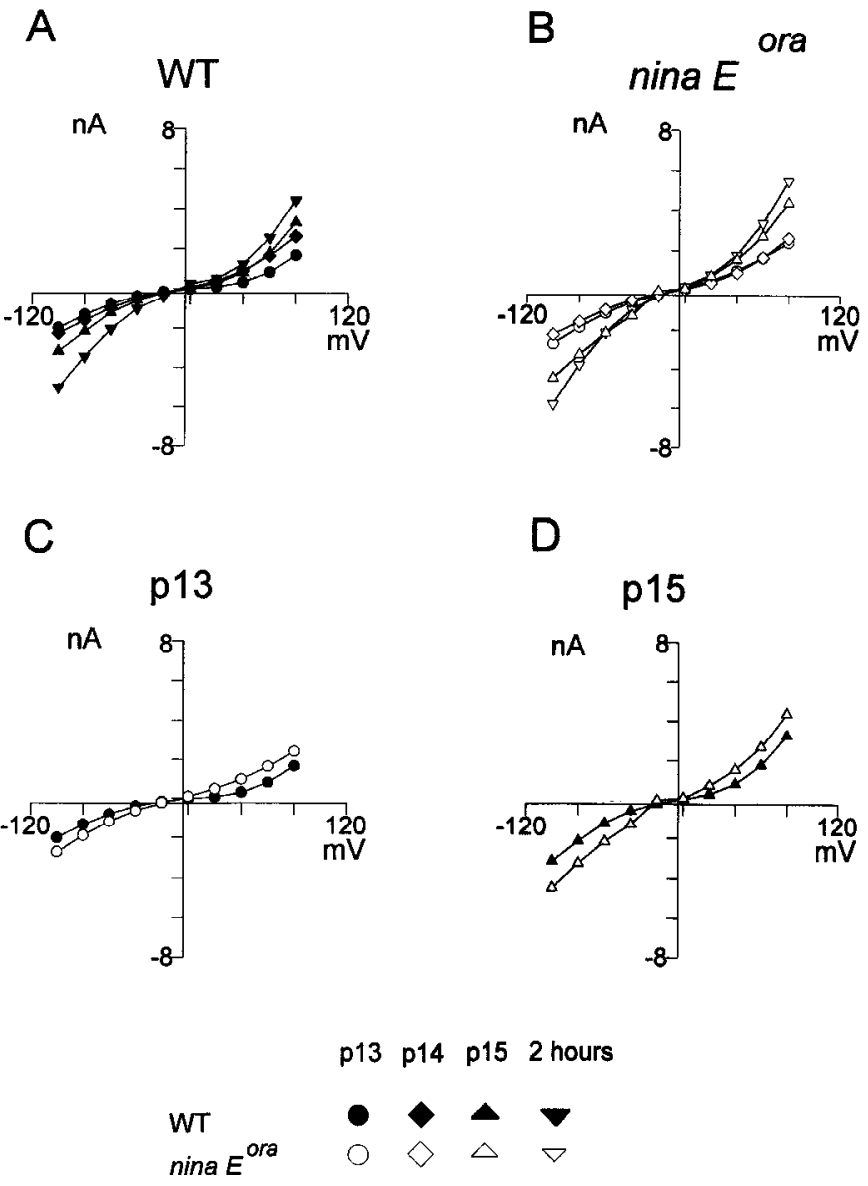

Figure 8. Current-voltage relationship of wild-type and ninaE ${ }^{\text {ora }}$ photoreceptors during rundown in zero $\mathrm{Ca}^{2+}$ Ringer's $(0.1 \mathrm{~mm}$ EGTA) at various developmental stages (from P13 to adult) as indicated. The data were plotted from experiments similar to that of Figure $6 D$. The RDC amplitude of each cell was sanpled at a constant time ( $30 \mathrm{msec}$ from pulse onset) and $I-V$ curves were plotted. The averages of $I-V$ curves from five to eight cells are presented. The magnitude of the RDC was larger in nina $E^{\text {ira }}$ at both positive and negative holding potentials at all developmental stages $(C, D)$. In both wild-type and nina $E^{\text {orr }}$ there is an increase in RDC with developmental age. The currents before rundown were subtracted from all points.

increased with age, but are larger in the mutant at all developmental stages. The amplitude of the RDC at $-60 \mathrm{mV}$ holding potential at the various experimental conditions is presented in Figure 9. Strikingly, at all developmental stages the amplitude of the RDC was significantly larger in ninaEora relative to wild type although the microvillar area in ninaEra was less than half of that in wild type. This result is consistent with the larger amount of TRP staining with MAb83F6 found in ninaE ${ }^{o r a}$ relative to wild type (Table 1) and shows that the surface area of the microvilli had no correlation with the functional expression of TRP.

Figure 4 shows that there are more microvilli in R1-R6 cells of ninaE $E^{o r}$ relative to wild type. To quantitate this difference, we counted the number of microvilli per rhabdomere in EM cross sections of wild type and ninaE $E^{\text {ora }}$ in stage $\mathrm{P} 13$ pupae and adults. These results are presented in Table 3, which shows that whilst the microvilli number increases (by ca. 30\%) with developmental age in both wild type and ninaEora, there are significantly more microvilli in nina $E^{\text {ora }}$ in both P13 and adult flies 


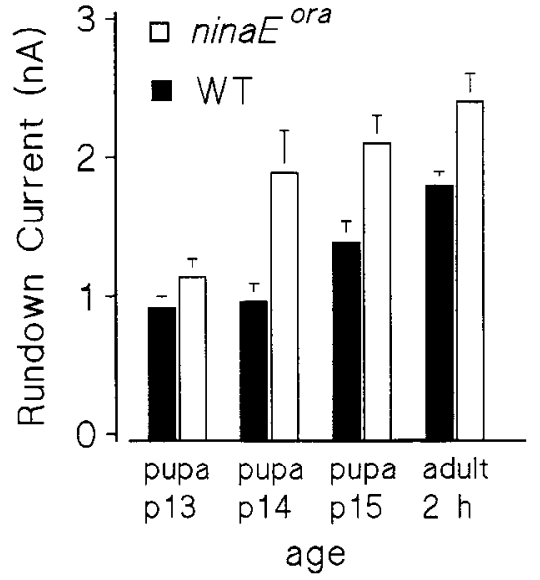

Figure 9. The magnitude of the RDC in wild type and ninaEra at various developmental stages. The amplitude of the RDC at $-60 \mathrm{mV}$ holding potential in zero $\mathrm{Ca}^{2+}$ Ringer's is compared between wild type and nina $E^{\text {ora }}$ at the various developmental stages. The averaged amplitude of the RDC increases with age in both wild type and ninatira. 'The RDC of the mutant was significantly larger than wild type at all developmental stages. Five to eight cells from different flies were used for the measurements in each stage. The error bars are SEM.

(15\% and $19 \%$ increase respectively relative to wild type). This increase is somewhat smaller than the increase in RDC amplitude in ninaE ${ }^{\text {ora }} \mathrm{P} 13$ and adult relative to wild type (e.g., 24\% and $33 \%$ larger RDC in the mutant, respectively). A close examination of the structure at the electron microscopic level showed enlargement of the membrane loops at the base of the microvilli in ninaEara relative to wild type (Fig. 4). This enlarged base area together with the greater number of microvilli may account for the larger RDC in nina $E^{\text {ora }}$ relative to wild type.

\section{Discussion}

The results presented here indicate that the TRP protein is primarily localized to the region near the base of the microvilli, and not to the entire length of the microvilli. This conclusion is based on two independent lines of evidence: (1) immunoreactivity staining using monoclonal anti-TRP antihndy (MAb83F6) and (2) electrophysiological measurements of TRP-dependent inward current of normal and mutant photoreceptors.

\section{Immunoreactivity staining}

Cross sections of wild-type ommatidia stained with anti-TRP antibody showed a "crescent" staining at the base of the microvilli, clearly indicating that little or no TRP was stained along the microvilli. The specificity of the staining indicated that MAb83F6 identified only TRP as demonstrated by the absence of staining in the presumably null $\operatorname{trp}$ alleles $\left(\operatorname{tr} p^{P 30 I}\right.$ and $\left.\operatorname{tr} p^{P .343}\right)$, and by the molecular cloning data from an identified expression clone.

Even though the ninaE ${ }^{\text {ora }}$ mutant had shorter microvilli and smaller rhabdomeric surfacc membranc as measured by wholecell capacitance, expression of the TRP protein appeared to be higher than normal. While the higher level of expression did not correlate with the reduced microvilli area, possible correlates are found in the greater number and increased size of the plasma membrane loops found at the base of the rhabdomere, and with the elevated TRP-dependent inward current (RDC). While the immunohistochemical and morphological data rule out the possibility of significant TRP localization throughout the microvillar
Table 3. Number of microvilli per R1-R6 rhabdomere

\begin{tabular}{ll} 
Fly & Microvilli \\
\hline WT (p13) & $23.3 \pm 1.6^{* *}$ \\
& $(n=9)$ \\
WT (1 day) & $29.7 \pm 1.3^{* *}$ \\
& $(n=8)$ \\
ninaE & $26.7 \pm 3.2^{* *}(\mathrm{p} 13)$ \\
ninaE & $(n=21)$ \\
& $35.2 \pm 2.7^{* * a}$ \\
& $(n=10)$
\end{tabular}

There is significant difference between WT (p13) and WT (1 d) as well as between ninaE $E^{m}$ (p13) and ninaEm (1 d). There is also a significant difference between WT (1 d) and ninaE'ma $(1 \mathrm{~d})$. Data are presented as \pm SEM.

** 5\% significance level in $t$ test.

membrane, it was not refined enough to determine if TRP is localized to the surface membrane, or to a submicrovilli structure. However, the functional localization of TRP at the surface plasma membrane is supported by electrophysiological data which clearly demonstrate a "dose-dependent" effect of TRP expression on membrane currents. Namely, when smaller

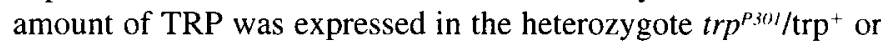
in $\operatorname{trp}{ }^{C M}$ raised at $19^{\circ} \mathrm{C}$ relative to $\mathrm{WT}$, smaller RDC was recorded.

$R D C$ measured in ninaE ${ }^{\text {ora }}$ supports the hypothesis that TRP is localized to the base of the microvilli

The RDC reflects spontaneous activation of both trp and nontrp dependent channels but its development appears to require the presence of trp dependent channels (Hardie and Minke, 1994,a,b). In addition, we have shown that the amplitude of the $\mathrm{RDC}$ is a sensitive measure of the levels of functional TRP protein, since it is reduced $(67 \%)$ in the heterozygote $\left(t r p^{p 301 /}\right.$ $\left.\operatorname{trp}^{+}\right)$and further reduced $(41 \%)$ in the $\operatorname{trp}{ }^{C M}$ mutant reared at the permissive temperature of $19^{\circ} \mathrm{C}$. Functional expression of TRP under these conditions was confirmed independently by a positive shift in $E_{\text {rev }}$ of the light-induced current.

Whole-cell capacitance is a sensitive measure of the surface membrane area. Most of this area (ca. $80 \%$ ) in adult wild type is due to the surface membrane of the microvilli. Since there is little change in rhabdomeral length or diameter beyond stage P13, the approximate doubling in whole-cell capacitance between P13 and adult in wild type can be largely attributed to the increase in length and number of the microvilli (Fig. 7; see also Hardie et al., 1993). In contrast to wild type, the whole-cell capacitance of ninaE ${ }^{\text {ora }}$ measured with developmental age did not increase. Since the microvilli number increase in this mutant, presumably their length must be simultaneously decreasing. Nevertheless, as in wild type the amplitude of the RDC in ninaE $E^{\text {ora }}$ also doubled its value during the period between P13 and adult. This increase in RDC probably reflects increase in TRP expression due to still unknown reason despite a decrease in microvillar length. Accordingly, the ninaE ${ }^{\text {ora }}$ data are not consistent with functional localization of TRP along the entire surface of the microvilli, but are consistent with localization at the base of the microvilli. Since the increase in TRP is manifested as an increase in current, the TRP protein is required for activation of plasma membrane channels. The simplest hypothesis to account for this observation is to assume that TRP is localized at the plasma membrane. The loop structure found at the base 
of the microvilli is independent of their length, but does depend on the number of microvilli. The larger RDC amplitude of ninaEra relative to wild type can be explained by the larger number and larger size of microvilli loops found in the mutant. This provides greater capacity for TRP protein at this localization.

It might be argued that the increase in RDC in ninaEra is due to an increase in the number of non-trp dependent channels (that remain in the trp mutant) because the RDC reflects activation of both trp and non-trp-dependent channels (Hardie and Minke, 1994a,b). However, in this case we expect that the channel noise superimposed on the RDC will be dramatically increased in ninaE ${ }^{o r a}$ because this noise appears to be dominated by activity of the non-trp-dependent channels (Hardie and Minke, 1994a). We found no significant difference in the RDC noise in wild type and ninaEora (Hardie and Minke 1994a) making this possibility unlikely.

\section{Functional implications of TRP localization}

A large body of evidence indicate that invertebrate photoreceptors use the inositol lipid signaling cascade for phototransduction (Fein et al., 1984; Brown et al., 1984; Fein, 1986; Devary et al., 1987; Payne et al., 1988; Bloomquist et al., 1988; Minke and Selinger, 1991; Ranganathan et al., 1991b; Hardie and Minke, 1993). Nevertheless, the final pathway of excitation leading to the opening of the light activated channels in the plasma membrane, resulting in $\mathrm{Ca}^{2+}$ and $\mathrm{Na}^{+}$entry, has remained controversial (Johnson, et al., 1986; Bacigalupo et al., 1990; Frank and Fein, 1991; Nagy, 1991; Stieve and Benner, 1992; Hardie and Minke, 1993; Shin et al., 1993). The gating mechanism of the light sensitive channels of invertebrates in general and of the trp-dependent channel in particular is therefore still unknown.

By analogy to vertebrate Ins $\mathrm{P}_{3}$-dependent $\mathrm{Ca}^{2+}$ entry channels (Irvine, 1991; Berridge, 1993; Penner et al., 1993), the so called "capacitative" $\mathrm{Ca}^{2+}$ entry (Putney, 1990), we have previously suggested that TRP may be activated by depletion of the $\operatorname{InsP}_{3}$ sensitive intracellular $\mathrm{Ca}^{2+}$ stores, possibly via direct proteinprotein interaction with the $\operatorname{InsP}_{3}$ receptor. The localization of TRP to the base of the microvilli is consistent with this hypothesis. In addition, detailed electron microscopic studies of the microvillar region in Drosophila (Matsumoto-Suzuki et al., 1989; Leonard et al., 1992) and our own observations indicate that the SMC are very close to, and practically touching the base of the microvilli. This is also consistent with either direct or indircet protein-protcin interaction between TRP and the $\operatorname{Ins} \mathrm{P}_{3}$ receptor.

\section{References}

Bacigalupo J, Lisman JE (1983) Single-channel currents activated by light in Limulus ventral photoreceptors. Nature 304:268-270.

Bacigalupo J, Johnson E, Robinson P, Lisman JE (1990) Second messengers in invertebrate phototransduction. In: Transduction in biological systems (Hidalgo C, Bacigalupo J, Jaimovich E, Vergara J, eds), pp 27-45. New York: Plenum.

Bainbridge SP, Bownes M (1981) Staging the metamorphosis of Drosophila melanogaster. J Embryol Exp Morphol 66:57-80.

Banerjee U, Renfranz PJ, Pollock JA, Benzer S (1987) Molecular characterization and expression of sevenless, a gene involved in neuronal pattern formation in the Drosophila eye. Cell 49:281-291.

Baumann O, Walz B (1989) Calcium- and inositol polyphosphate-sensitivity of the calcium-sequestering endoplasmic reticulum in the photoreceptor cells. J Comp Physiol [A] 165:627-636.

Berridge MJ (1993) Inositol trisphosphate and calcium signalling. Nature 361:315-325.

Bloomquist BT, Shortridge RD, Schneuwly S, Perdew M, Montell C,
Steller H, Rubin G, Pak WL (1988) Isolation of a putative phospholipase $\mathrm{C}$ gene of Drosophila, norpA, and its role in phototransduction. Cell 54:723-733.

Brown JE, Rubin LJ, Ghalayini AJ, Tarver AP, Irvine RF, Berridge MJ, Anderson RE (1984) myo-Inositol polyphosphate may be a messenger for visual excitation in Limulus photoreceptors. Nature 311:160163.

Cosens DJ, Manning A (1969) Abnormal electroretinogram from a Drosophila mutant. Nature 224:285-287.

Devary O, Heichal O, Blumenfeld A, Cassel D, Suss E, Barash S, Rubinstein CT, Minke B, Selinger Z (1987) Coupling of photoexcited rhodopsin to inositol phospholipid hydrolysis in fly photoreceptors. Proc Natl Acad Sci USA 84:6939-6943.

Feiler R, Harris WA, Kirschfeld K, Wehrhahn C, Zuker CS (1988) Targeted misexpression of a Drosophila opsin gene leads to altered visual function. Nature 333:737-741.

Fein A (1986) Excitation and adaptation of Limulus photoreceptors by light and inositol 1,4,5-trisphosphate. Trends Neurosci 9:110-114.

Fein A, Payne R, Corson DW, Berridge MJ, Irvine RF (1984) Photoreceptor excitation and adaptation by inositol 1,4,5-trisphosphate. Nature 311:157-160.

Frank TM, Fein A (1991) The role of the inositol phosphate cascade in visual excitation of invertebrate microvillar photoreceptors. J Gen Physiol 97:697-723.

Fujita SC, Zipursky SL, Benzer S, Ferrus A, Shotwell SL (1982) Monoclonal antibodies against the Drosophila nervous system. Proc Natl Acad Sci USA 79:7929-7933.

Hardie RC (1991) Whole-cell recordings of the light induced current in dissociated Drosophila photoreceptors: evidence for feedback by calcium permeating the light-sensitive channels. Proc R Soc Lond [Biol] 245:203-210.

Hardie RC, Minke B (1992) The trp gene is essential for a lightactivated $\mathrm{Ca}^{2+}$ channel in Drosophila photoreceptors. Neuron 8:643651.

Hardie RC, Minke B (1993) Novel $\mathrm{Ca}^{2+}$ channels underlying transduction in Drosophilaphotoreceptors: implications for phosphoinositide-mediated $\mathrm{Ca}^{2+}$ mobilization. Trends Neurosci 16:371-376.

Hardie RC, Minke B (1994a) Spontaneous activation of light sensitive channels in Drosophila photoreceptors. J Gen Physiol 103:389-407.

Hardic RC, Minkc B (1994b) Calcium-dependent inactivation of light sensitive-channels in Drosophila photoreceptors. J Gen Physiol 103: 409-427.

Hardie RC, Peretz A, Pollock JA, Minke B (1993) $\mathrm{Ca}^{2+}$ limits the development of the light response in Drosophila photoreceptors. Proc R Soc Lond [Biol] 252:223-229.

Harris WA, Stark WS, Walker JA (1976) Genetic dissection of the photoreceptor system in the compound eye of Drosophila melanogaster. J Physiol (Lond) 256:415-439.

Hochstrate $P$ (1989) Lanthanum mimics the trp photoreceptor mutant of Drosophila in the blowfly Calliphora. J Comp Physiol [A] 166: 179-187.

Hyde DR, Mecklenburg KL, Pollock JA, Vihtelic TS, Benzer S (1990) Twenty Drosophila visual system cDNA clones: one is a homolog of human arrestin. Proc Natl Acad Sci USA 87:1008-1012.

Irvine RF (1991) Inositol tetrakisphosphate as a second messenger: confusions, contradictions, and a potential resolution. Bioessays 13: 419-427.

Itoh N, Salvaterra P, Itakura K (1985) Dros Inf Serv 61:89.

Johnson EC, Robinson PR, Lisman JE (1986) Cyclic GMP is involved in the excitation of invertebrate photoreceptors. Nature 324:468-470.

Leonard DS, Bowman VD, Ready DF, Pak WL (1992) Degeneration of photoreceptors in rhodopsin mutants of Drosophila. J Neurobiol 23:605-626.

Matsumoto-Suzuki E, Hirosawa K, Hotta Y (1989) Structure of the subrhabdomeric cisternae in the photoreceptor cells of Drosophila melanogaster. J Neurocytol 18:87-93.

Minke B (1982) Light-induced reduction in excitation efficiency in the trp mutant of Drosophila. J Gen Physiol 79:361-385.

Minke B (1983) The trp is a Drosophila mutant sensitive to developmental temperature. J Comp Physiol [A] 151:483-486.

Minke B, Selinger Z (1991) Inositol lipid pathway in fly photoreceptors: excitation, calcium mobilization and retinal degeneration. In: Progress in retinal research (Osborne NA, Chader GJ, eds), pp 99124. Oxford: Pergamon 
Minke B, Wu C, Pak WL (1975) Induction of photoreceptor voltage noise in the dark in Drosophila mutant. Nature 258:84-87.

Montell C, Rubin GM (1989) Molecular characterization of the Drosophila trp locus: a putative integral membrane protein required for phototransduction. Neuron 2:1313-1323.

Montell C, Jones K, Hafen E, Rubin G (1985) Rescue of the Drosophila phototransduction mutation $a r p$ by germine transformation. Science 230:1040-1043.

Nagy K (1991) Biophysical processes in invertebrate photoreceptors: recent progress and a critical overview based on Limulus photoreceptors. Q Rev Biophys 24:165-226.

Nagy K, Stieve H (1990) Light-activated single channel currents in Limulus ventral photoreceptors. Eur Biophys J 18:221-224.

Nasi E (1991) Electrophysiological properties of isolated photoreceptors from the eye of Lima scabra. J Gen Physiol 97:17-34.

Nasi E, Gomez MP (1992) Light-activated ion channels in solitary photoreceptors of the scallop Pecten irradians. J Gen Physiol 99: 747-769.

O'Tousa JE, Baehr W, Martin RL, Hirsh J, Pak WL, Applebury ML (1985) The Drosophila ninaE gene encodes an opsin. Cell 40:839850.

O'Tousa JE, Leonard DS, Pak WL (1989) Morphological defects in ora ${ }^{\mathrm{K} \times 4}$ photoreceptors caused by mutation in R 1-6 opsin gene of Drosophila. J Neurogenet 6:41-52.

Pak WL (1979) Study of photoreceptor function using Drosophila mutants. In: Neurogenetics, genetic approaches to the nervous system (Breakfield X, ed), pp 67-99. New York: Elsevier/North Holland.

Paulsen R (1984) Spectral characteristics of isolated blowfly rhabdomers. J Comp Physiol [A] 155:47-55.

Payne R, Walz B, Levy S, Fein A (1988) The localization of calcium release by inositol trisphosphate in Limulus photoreceptors and its control by negative feedback. Philos Trans R Soc Lond [Biol] 320: 359-379.

Penner R, Fasolato C, Hoth M (1993) Calcium influx and its control by calcium release. Curr Opin Neurobiol 3:368-374.

Peretz A, Sandler C, Kirschfeld K, Hardie RC, Minke B (1994a) Genetic dissection of light-induced $\mathrm{Ca}^{2+}$ influx into Drosophila photoreceptors. J Gen Physiol 104:1057-1077.

Peretz A, Suss-Toby E, Rom-Glas A, Arnon A, Payne R, Minke B (1994b) The light response of Drosophila photorcceptors is accompanied by an increase in cellular calcium: effects of specific mutations. Neuron 12:1257-1267.

Perry MM (1968) Further studies on the development of the of Drosophila melanogaster. II. The interommatidial bristles. J Morphol 124:249-262.

Phillips AM, Bull A, Kelly LE (1992) Identification of a Drosophila gene encoding a calmodulin-binding protein with homology to the trp phototransduction gene. Neuron 8:631-642.

Pollock JA, Benzer S (1988) Transcript localization of four opsin genes in the three visual organs of Drosophila; Rh2 is ocellus specific. Nature 333:779-782.

Pollock JA, Lipson ED, Sullivan DT (1985) Analysis of microsomal flavoproteins from Phycomyces sporangiophores: candidates for the blue-light photoreceptors. Planata 163:506-516.
Putney JWJ (1990) Capacitative calcium entry revisited. Cell Calcium $11: 611-624$

Rall W (1969) Time constants and electrotonic length of membrane cylinders and neurons. Biophys J 9:1483-1508.

Rall W, Segev I (1985) Space clamp problems when voltage clamping branched neurons with intracellular microelectrodes. In: Voltage and patch-clamping with microelectrodes (Lecar H, Redman SJ, Gagc PW, eds), pp 191. Bethesda, MD: American Physiological Society.

Ranganathan R, Harris GL, Stevens CF, Zuker CS (1991a) A Drosophila mulant defective in extracellular calcium-dependent photoreceptor deactivation and rapid desensitization. Nature 354:230-232.

Ranganathan R, Harris WA, Zuker CS (1991b) The molecular genetics of invertebrate phototransduction. Trends Neurosci 14:486-493.

Ready DF, Hanson TE, Benzer S (1976) Development of the Drosophila retina, a neurocrystalline lattice. Dev Biol 53:217-240.

Rubinstein CT, Bar-Nachum S, Selinger Z, Minke B (1989) Lightinduced retinal degeneration in $r d g B$ (retinal degeneration $B$ ) mutant of Drosophila: electrophysiological and morphological manifestations of degeneration. Visual Neurosci 2:529-539.

Sambrook J, Fritsch EF, Maniatis T (1989) Molecular cloning: a laboratory manual. Cold Spring Harbor, NY: Cold Spring Harbor Laboratory.

Schinz RH, Lo M-VC, Larrivee DC, Pak WL (1982) Freeze-fracture study of the Drosophila photoreceptor membrane: mutations affecting membrane particle density. J Cell Biol 93:961-969.

Shin J, Richard EA, Lisman JE (1993) $\mathrm{Ca}^{2+}$ is an obligatory intermediate in the excitation cascade of Limulus photoreceptors. Neuron $11: 845-855$.

Stark WS, Sapp R (1987) Ultrastructure of the retina of Drosophila melanogaster: the mutant ora (outer rhabdomeres absent) and its inhibition of degeneration in $r d g B$ (retinal degeneration-B). J Neurogenet 4:227-240.

Stark WS, Sapp R, Carlson SD (1989) Ultrastructure of the ocellar visual system in normal and mutant Drosophila melanogaster. J Neurogenet 5:127-153.

Stieve H, Benner S (1992) The light-induced rise in cytosolic calcium starts later than the receptor current of the Limulus ventral photoreceptor. Vision Res 32:403-416.

Suss-Toby E, Selinger Z, Minke B (1991) Lanthanum reduces the excitation efficiency in fly photoreceptors. J Gen Physiol 98:849-868.

Van Vactor D Jr, Krantz DE, Reinke R, Zipursky SL (1988) Analysis of mutants in chaoptin, a photoreceptor cell-specific glycoprotein in Drosophila, reveals its role in cellular morphogenesis. Cell 52:281290.

Waddington $\mathrm{CH}$, Perry MM (1960) The ultrastructure of the developing eye of Drosophila. Proc R Soc Lond [Biol] 153:155-187.

Walz B (1982) Calcium-sequestering smooth endoplasmic reticulum in retinula cells of the blowfly. J Ultrastruct Res 81:240-248.

Wong F, Schaefer EL, Roop BC, LaMendola JN, Johnson Seaton D, Shao D (1989) Proper function of the Drosophila trp gene product during pupal development is important for normal visual transduction in the adult. Neuron 3:81-94.

Yeandle S (1958) Evidence of quantized slow potentials in the eye Limulus. Am J Ophthalmol 46:82-87.

Zuker CS, Cowman AF, Rubin GM (1985) Isolation and structure of a rhodopsin gene from $D$. melanogaster. Cell 40:851-858. 